\title{
OUTPUT GROWTH AND FLUCTUATIONS \\ THE ROLE OF FINANCIAL OPENNESS
}




\author{
OUTPUT GROWTH \\ AND FLUCTUATIONS \\ THE ROLE OF FINANCIAL OPENNESS ' \\ by Alexander Popov²
}
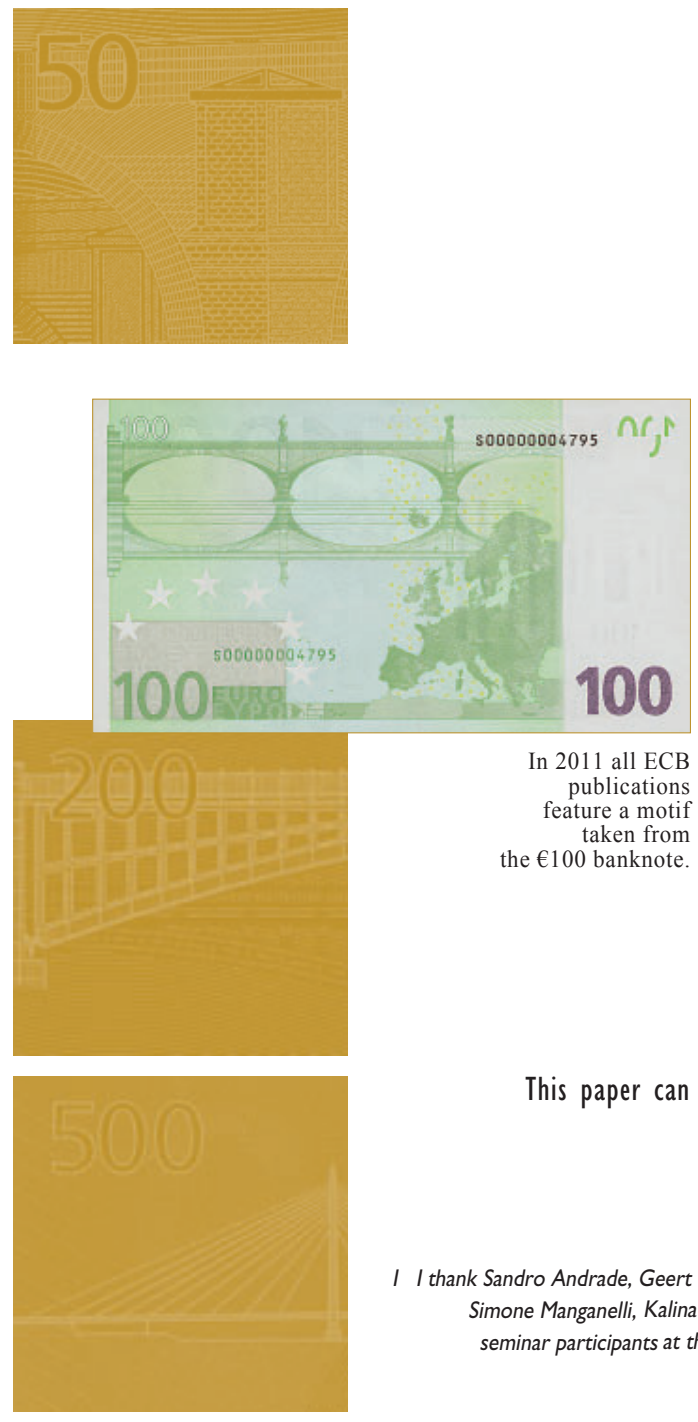

NOTE: This Working Paper should not be reported as representing the views of the European Central Bank (ECB).

The views expressed are those of the author and do not necessarily reflect those of the ECB.

This paper can be downloaded without charge from http://www.ecb.europa.eu or from the Social Science Research Network electronic library at http://ssrn.com/abstract_id=1910529.

I I thank Sandro Andrade, Geert Bekaert, Frederic Boissay, Pierre-Olivier Gourinchas, Philipp Hartmann, Marie Hoerova, Jean Imbs, Olivier Jeanne, Simone Manganelli, Kalina Manova, Steven Ongena, Valerie Ramey, Romain Ranciere, Helene Rey, Eric van Wincoop, Francis Warnock, and seminar participants at the ECB, at the 10th Darden International Finance Conference, and the 2011 EFA conference for useful discussion.

2 European Central Bank, Financial Research Division, Kaiserstrasse 29, D-603II Frankfurt, Germany, 
(C) European Central Bank, 2011

\section{Address}

Kaiserstrasse 29

60311 Frankfurt am Main, Germany

Postal address

Postfach 160319

60066 Frankfurt am Main, Germany

Telephone

+496913440

Internet

http://www.ecb.europa.eu

Fax

+496913446000

All rights reserved.

Any reproduction, publication and reprint in the form of a different publication, whether printed or produced electronically, in whole or in part, is permitted only with the explicit written authorisation of the ECB or the author.

Information on all of the papers published in the ECB Working Paper Series can be found on the ECB's website, http://www. ecb.europa.eu/pub/scientific/wps/date/ html/index.en.html

ISSN 1725-2806 (online) 


\section{CONTENTS}

Abstract

Non technical summary

1 Introduction

2 Data

3 Econometric framework

4 Empirical results

4.1 Financial openness, growth, volatility, and skewness: Main results

4.2 Financial openness, growth, volatility, and skewness: Selection bias

4.3 Financial openness, growth, volatility, and skewness: Industry effects

4.4 Financial openness, growth, volatility, and skewness: Data issues

4.5 Capital accumulation, productivity, new business creation, and employment

4.6 Financial openness, institutions, and economic fluctuations

4.7 Financial openness and skewness: Aggregate data evidence

5 Conclusion

References

Figures and tables 


\begin{abstract}
I analyze output growth, volatility, and skewness as the joint outcomes of financial openness. Using an industry panel of 53 countries over 45 years, I find that financial openness increases simultaneously mean growth and the negative skewness of the growth process. The increase in output skewness appears to come from a more negatively skewed distribution of investment, TFP, and new business creation. The growth benefits of financial liberalization are augmented, and its costs associated with higher probability of rare large contractions are mitigated by deep credit markets and by strong institutions. The main result of the paper holds in aggregated data.
\end{abstract}

JEL classification: E32, F30, F36, F43, G15.

Keywords: Financial openness, growth, volatility, skewness, development. 


\section{Non-technical summary}

Economic research has focused intensely in recent years on the implications of financial openness for the volatility of economic growth. However, from a welfare perspective, volatility is an inferior measure of risk than measures of rare and abrupt contractions in output (“disaster risk”). While it has been long established that the welfare benefits of removing all of the U.S. business cycle volatility are miniscule, changes in consumption uncertainty that reflect shifts in the probability of economic disaster can have major implications for welfare. In particular, within a class of models that replicate how asset markets price consumption uncertainty, individuals are willing to pay large insurance premia in exchange for eliminating all chances for large macroeconomic contractions. Therefore, it is essential to understand the contribution of financial openness to disaster risk, as well as the macroeconomic circumstances which mitigate any potential welfare loss without hindering the positive effect of financial openness on growth.

In this paper I examine the effect of financial openness, both de jure and de facto, on output growth and volatility, as well as on the probability of large and abrupt macroeconomic contractions, measured as the skewness of the distribution of output growth rates. Unlike the variance, the third moment of economic growth captures asymmetric and abnormal distributional patterns and is thus related to the concept of disaster risk. Large contractions happen occasionally, and so they tilt the distribution of growth rates to the left. Furthermore, because volatility deters growth and because mean growth and skewness may have common underlying determinants, I estimate the effect of financial openness on growth, volatility, and skewness jointly. Finally, I relate financial openness to economic and financial development in an attempt to gauge the importance of institutional complementarities in mitigating disaster risk.

The data on industrial output come from the Penn Tables (for the country level analysis) and from the 2010 UNIDO Industrial Statistics 2 Database (for the sector level analysis), and cover a period as long as 1963-2009. I require that each sector contains data on at least 10 years before and at least 10 years after a liberalization event (for countries which experienced liberalization), and data on at least 10 years before and at least 10 years after the average liberalization year (for countries which did not), and that each country has at least 10 such sectors. The resulting dataset consists of 53 countries. I combine these data with Kaminsky and Schmukler's (2008) liberalization chronology, defining a country as fully financially open after it has liberalized equity markets and credit markets and has lifted restrictions on international financial transactions. I complement this de jure index with de facto measures of financial integration, namely the gross capital flows measure from Lane and 
Milesi-Ferretti (2007), calculated as the sum of total foreign assets and total foreign liabilities, normalized by GDP.

The main finding of the paper is that financial openness increases simultaneously the rate, the volatility, and the negative skewness of output growth. This result is recorded regardless of whether I look at de jure (financial market liberalization events) or de facto (volume of international capital flows) measures of financial globalization, and of whether I use the country or the industry as my main unit of observation. I also find that following financial liberalization, the distribution of growth rates of capital accumulation, TFP growth, and new business creation has become more skewed to the left, while the distribution of employment growth rates has become more skewed to the right.

The second main result of the paper is that the direct effect of liberalization on negative skewness is higher than the overall effect. Estimating the effect of openness on the three moments of output growth simultaneously enables me to isolate the direct effect on each moment from the effect through other moments. This approach allows me to show that some of the effect of openness on skewness is mitigated through the channel of higher growth, implying that financial openness increases disaster risk more in the short-run than in the long-run.

My third main result is derived from examining the role of institutional complementarities in determining economic outcomes. In particular, I find that the welfare loss of financial liberalization in terms of a more negatively skewed distribution of growth rates is lower in countries with more developed domestic financial markets, as well as in countries with better institutions. The clear policy implication of these findings is that the welfare effects of liberalization vary with the degree of economic and financial development, therefore financial liberalization is not a one-size-fits-all policy.

While the main results appear robust to various econometric techniques which account for the nonrandomness of liberalization, as well as to alternative samples and measures of tail risk, further empirical work is needed to examine how this effect relates to the aggregate economy, and what are the welfare implications of this process in terms of consumption. Preliminary evidence indicates that international capital flows increase the risk of sudden large macroeconomic contractions, and that unlike output volatility, output skewness is not fully insured away by the government sector. To the extent that international capital flows are easily observable, this project yields clear insights for macroprudential regulators. 


\section{Introduction}

In an attempt to understand the benefits and costs of financial openness, economic research has focused intensely in recent years on the effect of openness on the rate and volatility of output growth. Scholars have provided robust empirical evidence that openness is associated, causally, with better prospects for future growth, especially in the case of stock market liberalization. ${ }^{1}$ Regarding the effect of financial openness on volatility, the verdict is still out. ${ }^{2}$

The combined evidence generates two important issues. First, using the volatility of output growth to derive welfare implications is questionable given arguments dating back to Lucas (1987) that the welfare benefits of removing all of the business cycle volatility are trivial. At the same time, Barro $(2006,2009)$ has recently demonstrated that within a class of models which replicate how asset markets price consumption uncertainty, individuals are willing to pay a high premium in exchange for eliminating all chances for rare, large, and abrupt macroeconomic contractions. ${ }^{3}$ To the extent that output risk cannot be fully insured, the same increase in volatility would have considerably larger negative implications for consumer welfare if it came from one single large contraction than if it came from a series of small symmetric deviations from a stable growth path.

To illustrate this point, consider the growth pattern of two hypothetical countries A and B. Country A's GDP growth is normally distributed, with a mean of 0.01 and a standard deviation of 0.024. Country B exhibits a steady annual growth rate of 0.0126 , with arbitrarily small symmetric

\footnotetext{
${ }^{1}$ Bekaert et al. (2005) show that equity market liberalization raises subsequent average annual real output growth by about 1\%, and Gupta and Yuan (2009) find an effect of an even larger magnitude at the industry level. Evidence on the growth effect of capital accounts liberalization has traditionally been more mixed, with no effect in Rodrik (1998a), and a positive effect driven by developed economies in Edwards (2001). However, Quinn and Toyoda (2008) estimate a strong causal effect and argue that prior conflicting evidence is due to the use of insufficiently long time periods and to not accounting properly for measurement error and for collinearity among independent variables.

${ }^{2}$ For example, Stiglitz (2000), Kose et al. (2003), and Levchenko et al. (2009) argue that foreign capital increases volatility both in the financial markets and in the real economy. However, Kaminsky and Schmukler (2008) find that financial openness is followed by large booms and busts only in the short run; still others find no effect of financial openness on macroeconomic volatility (Easterly et al., 2001), or even a negative effect when openness is proxied by stock market liberalization (Bekaert et al., 2002). For a comprehensive review of the literature on the growth and volatility effects of financial liberalization, see Kose et al. (2006), Henry (2007), and Bekaert et al. (2011), among others.

${ }^{3}$ This framework was first suggested by Rietz (1988) and has lately been extended to incorporate time-varying disaster incidence (Gabaix, 2008) and recoveries (Gourio, 2008).
} 
deviations from that average, but once every century its GDP declines by $25 \%$. Over a period of 100 years, country B attains the same mean growth rate and the same standard deviation of output growth as country A. However, with Epstein-Zin-Weil preferences and values for the intertemporal elasticity of substitution and the coefficient of relative risk aversion as in Barro (2009), society in the second country would willingly reduce GDP by around $10 \%$ each year to replace the country's long-term growth profile with that of country A (assuming that the government can insure none of the output shock away). ${ }^{4}$ To address this consideration properly, one would need to look at the effect of financial openness on the skewness of output growth which captures such asymmetic and abnormal distributional patterns and is thus related to the concept of tail risk. The literature has not done that so far.

Second, the existing evidence has been derived from empirical tests where output growth and output risk are treated as independent outcomes of financial openness. From a theoretical standpoint, however, it makes more sense for the evolution of growth and risk to be jointly determined. Volatility and growth have been shown to be negatively correlated at the country level (Ramey and Ramey, 1995; Aghion and Banerjee, 2005; Aghion et al., 2010), for example because aggregate shocks are large and important in low-growth economies. Volatility and growth have also been shown to be positively correlated at the industry level (Imbs, 2007), for example because high returns technologies entail high risks as in a mean-variance framework. Finally, growth and skewness may be the joint outcomes of the process of risk taking that characterizes financially open economies, as in Ranciere et al. (2008). Therefore, a more convincing empirical test would allow for the simultaneous determination of the first three moments of output growth. ${ }^{5}$

Addressing these two conceptual issues is what I set to do in this article. In particular, I use data on sector-level value added for a wide cross section of countries over the past 45 years to

\footnotetext{
${ }^{4}$ The main feature of the preference specification developed by Epstein and Zin (1989) and Weil (1990) is that it delinks the IES from the coefficient of relative risk aversion.

${ }^{5}$ In a similar vein, Lundberg and Squire (2003) and Mobarak (2005) show that allowing for the joint determination of various growth outcomes yields significantly different results and hence has different consequences for policy from studies based on independent tests.
} 
study the impact of financial liberalization on output growth, volatility, and skewness. I do so in a simultaneous equation framework which allows for the joint determination of the three moments of output growth. My main finding is that financial liberalization is followed by an increase in industry output growth and by an increase in the negative skewness of the output growth process. At the same time, the data suggest no statistical effect of financial openness on output volatility. These results are consistent with the view that financial constraints are reduced and investment is aligned with growth opportunities when financial markets are liberalized, as well as with the view that financial openness raises the probability of a collapse in industrial output following a sudden stop in capital flows. I also find that these effects are stronger in industries which are more externally dependent and which face better growth opportunities. I subject these findings to a wide variety of alternative experiments, including accounting for the endogeneity of liberalization, controlling for the channels through which concurrent policy reforms and macroeconomic developments affect the rate and the variability of the growth process, using different subsets of countries, and alternating between de jure and de facto measures of financial openness. My results remain remarkably robust.

Second, estimating growth and risk jointly allows me to separate the direct from the indirect effect of financial openness. I find that at the level of the industrial sector, higher growth leads to a more positively skewed distribution of growth rates. Financial openness thus has a negative direct effects on skewness, but this is offset by an indirect positive effect through the growth channel. This implies that liberalization increases tail risk more in the short run than in the long run.

Third, the growth effect of financial openness is primarily realized through a higher rate of TFP growth, while the increase in negative skewness is primarily realized through a more negatively skewed distribution of investment and TFP growth and of the rate of creative destruction. Employment growth seems to be relatively stable in the wake of financial market openness. These results expand on the analysis in Gupta and Yuan (2009) and Levchenko et al. (2009) by shedding light on the effect of liberalization on the asymmetric variability of the capital, productivity, establishments, and employment growth process. 
I also find that countries with deeper domestic credit markets and with more developed institutions, as well as Latin American economies, have benefited more from financial liberalization, both in terms of higher growth and in terms of lower tail risk. Finally, the negative effect of financial openness on skewness holds in the macro-level data as well, implying that it is not a feature of sectoral data which is averaged away in aggregation. While testing for whether the same pattern holds for consumption - in addition to output - growth is beyond the scope of this paper, my evidence tentatively suggests that in a world where agents are willing to pay high premia to avoid rare disasters, financial openness may be associated with a welfare cost that has not been identified before.

This paper is related to several recent papers which use data on sectoral output to study the real effects of financial openness. In particular, Gupta and Yuan (2009) use sectoral data to show that financial liberalization has a strong positive effect on output growth. Levchenko et al. (2009) look at the effect of liberalization on growth as well as on volatility at the sectoral level. I push this approach two steps further. First, I look at output skewness in addition to output volatility, in an attempt to capture better the asymmetric growth variability effect of financial openness. Second, I study the impact of liberalization on growth, volatility and skewness jointly. This empirical approach allows me to separate the direct from the indirect effect of liberalization. The results imply that relative to my approach, in an empirical strategy which estimates these effects independently, the direct growth effect of liberalization is likely to be overestimated, and its direct effect on tail risk is likely to be underestimated.

The empirical regularity investigated in this paper is most closely related to Ranciere et al. (2008) who study the link between financial liberalization, growth, and financial crises. In their model, in a financially liberalized economy with limited contract enforcement, systemic risk taking reduces the effective cost of capital and relaxes borrowing constraints. This allows greater investment and generates higher long-term growth, but it raises the probability of a sudden collapse in financial intermediation when a crash occurs. Systemic risk thus increases mean growth even if 
crises have arbitrarily large output and financial distress costs. While the authors test empirically the link between long-term growth and financial fragility, proxied by the skewness of domestic credit growth, my paper presents the first direct test of the link between financial openness, output growth, and output skewness. This is a paper about the pattern of economic fluctuations, not about financial crises.

The paper proceeds as follows. Section 2 describes the data. Section 3 presents the empirical methodology. Section 4 reports the main results, alongside a battery of robustness tests. Section 5 concludes.

\section{Data}

The main data used in the empirical analysis come from the 2010 UNIDO Industrial Statistics 2 Database. I use the version that reports data according to the 2-digit level of ISIC Revision 3 classification for the period 1963-2007. The data contain information on value added, capital, employment, and number of establishments for 21 manufacturing sectors in the best case, as well as for total manufacturing. ${ }^{6}$ Similar to Levchenko et al. (2009) and following Heston et al. (2002), I use the data reported in current U.S. dollars and convert them into international dollars using the Penn World Tables. ${ }^{7}$ I require that each sector contains data on at least 10 years before and at least 10 years after a liberalization event (for countries which experienced liberalization), and data on at least 10 years before and at least 10 years after the average liberalization year (for countries which did not), and that each country has at least 10 such sectors. The resulting dataset consists of 53 countries. $^{8}$

For each country-industry-period, I calculate the first three moments of output growth. I cal-

\footnotetext{
${ }^{6}$ Data are not available for two additional industries, Motor vehicles, trailers, semi-trailers, and Recycling.

${ }^{7}$ The exact mechanism is as follows. Using the variable name conventions from the Penn World Tables, this deflation procedure involves multiplying the nominal U.S. dollar value by $(100 / \mathrm{P}) *(\mathrm{RGDPL} / \mathrm{CGDP})$ for output to obtain the deflated value. See Levchenko et al. (2009) for more details.

${ }^{8}$ In robustness tests, I require that the countries have data on at least 20 years for at least $3 / 4$ and even 9/10 of all sectors, resulting in a further reduction in the number of countries available (reducing the cross section of countries to 45 and 20, respectively). See Section 4.4.2 for details.
} 
culate average real output growth in country $c$ and industry $s$ during period $t, \bar{g}_{c s}$, after taking differences in annual log output. Then, the sample standard deviation of real output growth in country $c$ and industry $s$ during period $t$ is defined as $\left(\frac{1}{T} \sum_{\tau=1}^{T}\left(g_{c s \tau}-\bar{g}_{c s}\right)^{2}\right)^{\frac{1}{2}}$, and the sample skewness of output growth of industry $s$ in country $c$ during period $t$ is calculated as $\frac{\frac{1}{T} \sum_{\tau=1}^{T}\left(g_{c s \tau}-\bar{g}_{c s}\right)^{3}}{\left(\frac{1}{T} \sum_{\tau=1}^{T}\left(g_{c s \tau}-\bar{g}_{c s}\right)^{2}\right)^{\frac{3}{2}}}$, where $\tau=1, \ldots, T$ are all years with observations in period $t$.

The literature on financial liberalization uses various measures of de jure and de facto liberalization. Quinn (1997), Bekaert et al. (2005), Bekaert et al. (2007), and most recently Kaminsky and Schmukler (2008) have dated various liberalization events pertinent to capital accounts, credit markets, and equity markets. Similar to Levchenko et al. (2009), I use the Kaminsky-Schmukler liberalization chronology, and I define a country as fully liberalized when all three indices of market liberalization - equity markets, credit markets, and international financial transactions - attain a value of 3 (fully liberalized). I complement this normative index with de facto measures of financial globalization, namely the gross capital flows measure from Lane and Milesi-Ferretti (2007), calculated as the sum of total foreign assets and total foreign liabilities, normalized by GDP.

Arguably, this definition of liberalization is rather noisy. From a neoclassical perspective, equity markets liberalization is expected to result in the largest effect on growth. Improved risk sharing post-liberalization should decrease the cost of equity capital (see, for example, Bekaert and Harvey, 2000) and increase investment (see, for example, Bekaert et al., 2005), therefore affecting the distribution of growth rates. In that sense, my results should be interpreted as a lower bound of the effect of liberalization on the distribution of growth rates. In the context of a more disaggregated analysis of the effect of stock market liberalization, Gupta and Yuan (2009) show that industries exhibit strictly higher growth rates in countries with liberalized equity markets. In (unreported) robustness tests, I use data from Bekaert et al. (2005) to investigate the research question at hand focusing exclusively on equity market liberalization episodes, but there are too few non-liberalized 
countries in the sample to make the results convincing.

Table 1 summarizes the three moments of output growth for the countries in the sample. It also contains information on the liberalization events that are used in the empirical exercises.

Countries with liberalized financial markets are usually more developed in a host of other dimensions: they tend to have better institutions, more developed domestic financial markets, higher human capital, and be more open to trade. All of these parallel macroeconomic circumstances may be affecting both the rate (see Acemoglu et al., 2003) and the variability (see Raddatz, 2006) of growth. Therefore, I collect data on institutional quality from Polity IV, on domestic credit to private institutions from Beck et al. (2010), on years of schooling from the Barro and lee database, on life expectancy and school enrollment from the World Development Indicators, and on population and trade openness from the World Penn Tables, to control directly for these effects. Table 2 summarizes the main control variables by country.

Finally, identification in the paper rests on carrying out the analysis at the industry level, which allows to control for various channels through which other concurrent macroeconomic processes like financial development, trade openness, etc. - may affect the rate and variability of output growth. As argued by Rajan and Zingales (1998), the distribution of growth rates would be most sensitive to financial development in industries which are "naturally" dependent on external finance. Such "natural" dependence may arise due to variations in the scale of projects, gestation period, the ratio of hard vs. soft information, the ratio of tangible vs. intangible assets, follow-up investments, etc. I use the measure of external financial dependence originally proposed by Rajan and Zingales (1998) for SIC 3-digit industries and later adapted by Cetorelli and Strahan (2006) for SIC 2-digit industries. The benchmark is defined as the industry median value of the sum across years of total capital expenditures minus cash flow from operations, divided by capital expenditures, for mature Compustat firms. ${ }^{9}$ Industry growth rates also tend to be affected by growth opportunities

\footnotetext{
${ }^{9}$ The exact procedure involves subtracting from the sum across years of total capital expenditures (Compustat item \#128) the cash flow from operations, i.e., revenues minus nondepreciation costs (Compustat item \#110) for each firm in Compustat, and then taking the median industry value as the benchmark.
} 
at the country level (Fisman and Love, 2007; Bekaert et al., 2007). Sectors which face higher global growth opportunities should grow faster post-liberalization. To address that point, I use data from Fisman and Love (2007) on industry sales growth in the US to account for this channel. Also, the variability of growth is also negatively affected by financial development if industries exhibit naturally high liquidity needs (Raddatz, 2006), and so I use this measure aggregated at the SIC 2-digit level. ${ }^{10}$ These three industry benchmarks are interacted with data on private credit to GDP from Beck et al. (2010). Finally, in order to account for the effect of international trade on output volatility and skewness, I re-weight the industry measures of the ratio of imports and exports to total output from di Giovanni and Levchenko (2009) for the SIC 2-digit level, and interact with data on trade openness from the Penn Tables.

Table 3 lists the industries included in the dataset and summarizes all industry benchmarks. For definitions of all variables included in the paper, alongside variable sources, see Appendix.

\section{Econometric framework}

I start by estimating the following system of equations:

$$
\begin{gathered}
\text { Growth }_{c s t}=\alpha \cdot \text { Post }_{t}+\beta \cdot \text { Lib }_{c t}+\gamma \cdot X_{c s t}^{1}+\delta \cdot \psi_{c s t}+\varepsilon_{c s t} \\
\text { Stdev }_{c s t}=\alpha \cdot \text { Post }_{t}+\beta \cdot \text { Lib }_{c t}+\gamma \cdot X_{c s t}^{2}+\delta \cdot \psi_{c s t}+\varepsilon_{c s t} \\
\text { Skewness }_{c s t}=\alpha \cdot \text { Post }_{t}+\beta \cdot \text { Lib }_{c t}+\gamma \cdot X_{c s t}^{2}+\delta \cdot \psi_{c s t}+\varepsilon_{c s t}
\end{gathered}
$$

Post is a dummy variable equal to 1 after the liberalization event, for countries which liberalized their financial markets, and equal to 1 after the average liberalization year for the sample, for

\footnotetext{
${ }^{10}$ The exact procedure involves dividing the value of total inventories (Compustat item \#3) by the value of total sales (Compustat item \#12) for each firm in Compustat, and then taking the median industry value as the benchmark.
} 
countries which did not. Lib is a dummy variable equal to 1 after the liberalization event, for countries which liberalized their financial markets. $X_{c s t}^{i}, i=1,2$, are vectors of various controls which are predicted by theory to affect the distribution of output growth rates; the two sets of variables overlap but are not identical across the three equations. In particular, all three models include industry s's beginning-of-period share in total manufacturing value added in country $c$ during period $t$; country $c$ 's beginning-of-period log GDP per capita and ratio of private credit to GDP during period $t$; and interactions of industry s's export and import intensity with beginningof-period trade openness in country $c$ during period $t$. In addition, $X_{c s t}^{1}$ contains interactions of industry $s$ 's dependence on external finance and growth opportunities with country c's beginningof-period ratio of private credit to GDP during period $t$, and $X_{c s t}^{2}$ contains the log of country c's beginning-of-period population during period $t$ and interactions of industry s's liquidity needs with country c's beginning-of-period ratio of private credit to GDP during period $t$ and with the $\log$ of country c's beginning-of-period population during period $t . \psi_{c s t}$ is a matrix of country, sector, and time fixed effects which control for a variety of omitted unobservable factors. Finally, $\varepsilon_{c s t}$ is the idiosyncratic error. Because financial liberalization is measured at the country $\times$ time level, I cluster the standard errors at the country $\times$ time level as well, in order to avoid biasing the standard errors downwards.

The basic econometric test is one in which the three equations are estimated independently using ordinary least squares (OLS). In that sense, this test relates to two disjoint sets of literature: the one which has studied the effect of financial openness and domestic financial development on growth (Beck et al., 2000; Bekaert et al., 2005, 2007; Gupta and Yuan, 2009), and the one which has studied the effect of the same processes on the volatility of output or consumption growth (Easterly et al., 2001; Bekaert et al., 2006; Raddatz, 2006). In addition, Levchenko et al. (2009) estimate the effect of financial liberalization on both output growth and volatility, but they treat the two processes independently. Neither approach is fully convincing from a theoretical standpoint: the evolution of growth and growth volatility, as well as skewness, may be the outcome of a similar 
process, and so they may be jointly determined by overlapping sets of factors.

To account for that possibility, I also estimate equations (1)-(3) simultaneously using a threestage least square (3SLS) methodology. If there were no unobserved differences across countries and no endogeneity, the model could be estimated as a pair of seemingly unrelated regressions (SUR) on pooled data. However, one needs to allow for the possibility that the volatility of growth affects growth rates (Ramey and Ramey, 1995; Mobarak, 2005; Aghion et al., 2010). Furthermore, one needs to allow for the possibility that anticipated higher growth may affect the skewness of the distribution of growth rates through risk taking (Ranciere et al., 2008). Because in the joint estimation the standard deviation of growth appears as a regressor in the growth equation and average growth appears as a regressor in the skewness equation, they need to be instrumented using exclusion restrictions. This condition is satisfied by the fact that as in the OLS case, the interactions of credit to the private sector with the sector's external financial dependence and growth opportunities are excluded from the volatility and skewness equations, and the log of population size (our diversification measure), as well as the interactions of the log of population size and credit to the private sector with the sector's liquidity needs are excluded from the growth equation.

The 3SLS empirical procedure therefore takes the following form:

$$
\begin{aligned}
\text { Growth }_{\text {cst }} & =\alpha \cdot \text { Post }_{t}+\beta \cdot \text { Lib }_{c t}+\gamma \cdot X_{c s t}^{1}+\theta \cdot \text { Stdev }_{c s t}+\delta \cdot \psi_{\text {cst }}+\varepsilon_{c s t} \\
\text { Stdev }_{c s t} & =\alpha \cdot \text { Post }_{t}+\beta \cdot \text { Lib }_{c t}+\gamma \cdot X_{c s t}^{2}+\delta \cdot \psi_{\text {cst }}+\varepsilon_{c s t} \\
\text { Skewness }_{c s t} & =\alpha \cdot \text { Post }_{t}+\beta \cdot \text { Lib }_{c t}+\gamma \cdot X_{c s t}^{2}+\theta \cdot \text { Growth }_{c s t}+\delta \cdot \psi_{c s t}+\varepsilon_{c s t}
\end{aligned}
$$

Finally, by applying a 3SLS procedure, I account for the possibility that the error terms in the three equations may have a nonzero covariance (which I expect them to, given that the three moments of growth are jointly determined).

In various robustness tests, in both the OLS and the 3SLS case, I replace de jure liberalization with de facto liberalization to control for the possibility that de jure liberalization captures poorly the actual financial integration of the domestic economy in the world economy (Levchenko et al., 
2009). To that end, I replace the de jure index of liberalization with a measure of capital flows from Lane and Milesi-Ferretti (2007).

The empirical approach so far is clearly based on a standard difference-in-differences analysis in which the coefficient of interest, $\beta$, measures the difference in change from pre- to post-liberalization between the treatment group and the control group. I choose two types of control groups for this exercise. First, I use all non-liberalized countries as a control group. This approach, however, does not account for the possible endogeneity of liberalization. Liberalization may be a strategic decision correlated with a variety of circumstances unobservable to the econometrician. For instance, it may be correlated with growth opportunities and thus made in anticipation of higher future growth (Bekaert et al., 2005). To control for that possibility, I borrow from the propensity score literature pioneered by Rosenbaum and Rubin (1983) and first run a first-stage logistic regression on a set of country level variables to determine what macro variables were correlated with the decision to liberalize. ${ }^{11}$ Based on the propensity score, I choose for each treated country a country that is most similar to it, and run the second-stage regression on this subset of control countries. The idea is to eliminate the potential selection bias arising from the fact that countries were not assigned the "treatment" randomly - that is, only systematically different countries liberalized their financial markets, and these systematic differences cannot be perfectly dealt with through the inclusion of covariates in the OLS regression because the distribution of the covariates does not overlap sufficiently across the two groups. This approach relates to earlier work in international economics by Persson (2001), Glick et al. (2006), and Levchenko et al. (2009).

I also want to investigate the impact of financial liberalization across industries. To that end, I modify the empirical strategy to take further advantage of the disaggregated data. In particular, I estimate the system of simultaneous equations

\footnotetext{
${ }^{11}$ The set includes pre-liberalization measures of economic development, financial development, institutional quality, human capital, and trade openness, among others.
} 


$$
\begin{aligned}
& \text { Growth }_{c s t}=\beta \cdot \text { Fin lib }_{c t} \cdot \text { Benchmark }_{s}^{1}+\gamma \cdot X_{c s t}^{1}+\theta \cdot \text { Stdev }_{c s t}+\delta \cdot \psi_{c s t}+\varepsilon_{\text {cst }} \\
& \text { Stdev }_{\text {cst }}=\beta \cdot \text { Fin lib }_{c t} \cdot \text { Benchmark }_{s}^{2}+\gamma \cdot X_{c s t}^{2}+\delta \cdot \psi_{c s t}+\varepsilon_{c s t} \\
& \text { Skewness }_{\text {cst }}=\beta \cdot \text { Fin lib } \\
& \text { st }
\end{aligned}
$$

In this modification, Fin lib is, alternatively, the de jure index Lib from systems (1) and (2), or a de facto measure of financial globalization in the shape of the gross capital flows measure from Lane and Milesi-Ferretti (2007). These variables are interacted with the industry benchmarks identified above. This robustness check allows me to establish whether the effect of liberalization on growth and risk is equally strong for various measures of liberalization, and more so for industries which are naturally more sensitive to financial market development. The specification also allows to include country $\times$ time fixed effects that capture other time-varying country characteristics that are not picked up by the controls.

Finally, I study which attributes of the macroeconomic environment tend to alleviate/exacerbate the positive/negative effects of financial liberalization in terms of growth and risk. To that end, I estimate the system of equations

$$
\begin{aligned}
\text { Growt }_{c s t} & =\alpha \cdot \text { Post }_{t}+\beta \cdot \text { Lib }_{c t} \cdot Z_{c t}+\gamma \cdot X_{c s t}^{1}+\theta \cdot \text { Stdev }_{c s t}+\delta \cdot \psi_{c s t}+\varepsilon_{c s t} \\
\text { Stdev }_{c s t} & =\alpha \cdot \text { Post }_{t}+\beta \cdot \text { Lib }_{c t} \cdot Z_{c t}+\gamma \cdot X_{c s t}^{2}+\delta \cdot \psi_{c s t}+\varepsilon_{c s t} \\
\text { Skewness }_{\text {cst }} & =\alpha \cdot \text { Post }_{t}+\beta \cdot \text { Lib }_{c t} \cdot Z_{c t}+\gamma \cdot X_{c s t}^{3}+\theta \cdot \text { Growth }_{c s t}+\delta \cdot \psi_{c s t}+\varepsilon_{c s t}
\end{aligned}
$$

Here, $Z_{c t}$ is a matrix of country level variables including measures of financial development, economic development, institutional quality, human capital, etc. This model is consistent with tests of the heterogeneous effects of financial liberalization in Bekaert et al. (2005) and Kose et al. (2006), among others. 


\section{Empirical results}

This section discusses the results of estimating the above empirical models. I report the main results in Section 4.1. Section 4.2 presents my strategy for dealing with endogeneity concerns. In Section 4.3, I investigate the impact of liberalization across industries. Section 4.4 presents a battery of data robustness tests. In Section 4.5 I study the channels through which liberalization affects the distribution of growth rates. Section 4.6 investigates the heterogeneous effect of liberalization across countries. In Section 4.7, I check whether the main results hold in aggregate data.

\subsection{Financial openness, growth, volatility, and skewness: Main results}

I begin by taking the main model to the data. The first three columns of Table 4 report the estimates of equations (1)-(3) where the effect of liberalization on growth, volatility, and skewness is estimated individually. Columns (4)-(5) report the estimates from model (4) where the three equations are estimated simultaneously. In both cases, I apply a difference-in-differences approach where the control group is all countries that have not liberalized their equity markets, credit markets, and capital accounts during the sample period. The regressions include country, industry, and time fixed effects, as well as a host of covariates.

When I estimate the three equations individually, I find that financial openness increases the rate and variability of output growth, in the case of the latter both in terms of volatility and in terms of negative skewness. All three effects are economically significant too. A financial liberalization event, captured by moving the $L i b$ variable from 0 to 1 , is associated with a sector-level growth rate higher by 2.9 percentage points. This is equivalent to 0.36 of a standard deviation of the average sector-level growth rate observed in the sample. The same financial liberalization event is associated with a sector-level negative skewness higher by 0.19 of a standard deviation of the average sector-level skewness observed in the sample. In the dimension of volatility, the effect is less economically significant (volatility increases by 0.11 of a sample standard deviation in the wake of liberalization). 
In columns (4)-(6), I investigate to what degree the effects estimated from running models (1)(3) are contaminated by the simultaneous determination of the three moments of growth. I include the volatility of growth in the growth equation, and average growth in the skewness equation, and then estimate the three equations in model (4) simultaneously. This allows me to dissect the effect of liberalization on the first three moments of growth into a direct effect (for example, liberalization affects the skewness of the distribution of growth) and an indirect effect (for example, liberalization affects growth, which in turn affects the skewness of the distribution of growth). I find once again a positive effect on growth and tail risk, but the magnitude of these effects changes somewhat. After controlling for the effect of financial liberalization on volatility, the effect on growth declines by about $1 / 3$, and after controlling for the effect of liberalization on growth, the effect on skewness almost triples, to 0.52 of a sample standard deviation. The effect of openness on volatility is no longer significant.

These results suggest that previous empirical work which has focused on the effect of financial liberalization on output growth and risk separately, may have overestimated or underestimated the true effects. For example, we know that at the industry level higher growth is associated with higher volatility (Imbs, 2007). My tests imply that financial liberalization increases the volatility of growth at the sector level, and so tests which do not account for the indirect effect through volatility overstate the direct effect of liberalization on growth. Similarly, higher growth is associated with more positive skewness (Columns (3) and (6)). I find that the direct negative effect of financial liberalization on the skewness of the distribution of growth rates is counteracted by the indirect positive effect through the growth channel. The direct effect is thus much more pronouncedly negative than the total effect.

It is also informative to note the effect of the industry and country covariates on growth and output variability. Larger sectors tend to be less volatile, but they tend to have a lower skewness. Importing sectors exhibit lower average growth rates. Countries with larger financial markets tend to have less volatile growth, especially for sectors with high liquidity needs, which is consistent 
with Raddatz (2006). Sectors with higher external financial needs and sectors which face higher growth opportunities exhibit lower growth rates in countries with more developed domestic financial markets. While this looks counterintuitive at first glance, going against the evidence in Rajan and Zingales (1998) and Fisman and Love (2007), the apparent contradiction is resolved by noticing that this effect is observed after netting out the effect of concurrent financial liberalization. Finally, diversification opportunities, proxied by population size, are associated with lower risk, especially for industries with high liquidity needs, which is consistent with Mobarak (2005) and Raddatz (2006).

\subsection{Financial openness, growth, volatility, and skewness: Selection bias}

Countries which liberalized their financial markets may have been systematically different, implying that liberalization may have been a strategic choice (Bekaert et al., 2005). In this section, I explicitly account for this possibility. Table 5 reports estimates from regressions where each liberalized country is first matched with a similar non-liberalized country based on a propensity score derived from a logistic regression. The variables used in the first stage to estimate the propensity score include pre-liberalization economic development (proxied by GDP per capita and GDP growth volatility), trade openness, institutional quality (proxied by creditors rights), human capital (proxied by secondary school enrollment), and financial development (proxied by the ratio of private credit to GDP). This procedure accounts for the possibility that, for example, countries liberalize in order to take advantage of a large pool of specialized human capital, and so the measured postliberalization increase in growth rates is partly due to the independent effect of human capital on growth.

The estimates from the propensity-score matching procedure are not weakened in a statistical sense when I restrict the control sample to the group of countries that are pair-wise most similar to the liberalized countries. When models (1)-(3) are estimated, I find that a financial liberalization event, captured by moving the $L i b$ variable from 0 to 1 , is associated with a sector-level growth rate 
higher by 1.7 percentage points, a sector-level volatility higher by 0.15 standard deviations, and a sector-level skewness lower by 0.38 standard deviations. (Columns (1)-(3)). As in the case when the full sample of non-liberalized countries is used as a control group, accounting for the indirect effect on growth through the volatility channel and on skewness through the growth channel results in a lower direct economic effect of liberalization on growth and a higher direct effect on the left skewness of the distribution of growth rates. I conclude that the estimated effects of financial liberalization are not due to liberalizing countries being systematically different from non-liberalizing ones over a range of observable macroeconomic characteristics.

\subsection{Financial openness, growth, volatility, and skewness: Industry effects}

While the empirical approach in the previous subsection should alleviate concerns about estimation bias caused by selection on observables, concerns about selection on unobservables still linger. Because in the empirical model financial openness varies at the country $\times$ time level, I cannot include country $\times$ time fixed effects that would capture any other time-varying characteristics not picked up by the controls. Recall, for example, the model in Ranciere et al. (2008) which implies that systemic risk taking increases the correlation between growth and crises. If countries liberalize when growth opportunities are abundant, regressions of future growth and skewness on a liberalization indicator will yield upward biased estimates. To that end, in this subsection I proceed to check whether the estimates so far are not driven by the fact that financial liberalization events may be correlated with other unobservable developments at the country level.

My approach to dealing with this potentially confounding problem is to employ a cross-country cross-industry methodology in the spirit of Rajan and Zingales (1998). In particular, I interact the main liberalization variable with industry benchmarks for external financial dependence, growth opportunities, and liquidity needs (Model (5)). The extant literature suggests that the following three hypotheses can be formulated:

1) By lowering the cost of external capital (Henry, 2000; Bekaert and Harvey, 2000), financial 
liberalization will lead to higher growth in industries that are more dependent on external finance.

2) By improving the alignment between capital and growth opportunities (Fisman and Love, 2007; Bekaert et al., 2007), financial liberalization will lead to higher growth in industries that face better growth opportunities.

3) By reducing information asymmetries and alleviating firms' temporary cash flows and/or net worth problems (Caballero and Krishnamurty, 2001), financial liberalization will lead to lower output volatility in industries that have higher liquidity needs.

The first two hypothesis are identical to Gupta and Yuan (2009). In addition, Love (2003) shows that investment is less sensitive to internal funds at the firm level in financially developed countries. The third is consistent with the theory outlined and the evidence presented in Raddatz (2006)

The results from the set of regressions formulated in Model (5) are reported in Table 6. Consistent with hypothesis 1 and 2, I find that industries that are more dependent on external finance and/or face higher growth opportunities grow significantly faster following liberalization. This effect is statistically significant as well. Numerically, a financial liberalization event is associated with $0.4 \%$ higher growth if the industry is at the 75 th rather than the 25 th percentile of external financial dependence, and with $0.8 \%$ higher growth if the industry is at the 75 th rather than the 25th percentile of growth opportunities.

Turning to output volatility and skewness, I find mixed results. Financial liberalization is associated with lower volatility in industries dependent on external finance (Column (2)), but with higher volatility for industries with high liquidity needs (Column (8)). However, financial liberalization is uniformly associated with more negative skewness. For example, a financial liberalization event is associated with $20.2 \%$ higher negative skewness if the industry is at the 75 th rather than the 25th percentile of liquidity needs. The effect of the rest of the industry- and country-level variables (unreported for brevity) is broadly consistent with previous estimates. 


\subsection{Financial openness, growth, volatility, and skewness: Data issues}

\subsubsection{De jure vs. de facto liberalization}

It has been argued that de jure measures of liberalization capture poorly the actual degree of financial market integration (e.g., Lane and Milesi-Ferretti, 2007). While conducive to the increase in foreign investment in domestic securities, an act of market liberalization may result in different magnitudes of actual integration with the world's financial markets (Levchenko et al., 2009), and some non-liberalized countries could in reality be more integrated than some liberalized ones. I aim to partially counter this problem by replacing the de jure indicator of liberalization with a de facto measure of financial globalization based on the gross foreign assets measure from Lane and Milesi-Ferretti (2007). Essentially, this variable estimates the actual exposure of a country's economy to foreign investors. The advantage of this method is that it captures better the degree to which various degrees of financial globalization within the set of financially liberalized countries map into differences in growth and risk.

The results of this version of Model (4) are reported in Table 7. As before, I account for the natural characteristics of the sector, in particular for dependence on external finance, which according to the results reported in Table 6 - is statistically most strongly associated with an effect of openness on growth and skewness. I find that higher gross foreign assets are associated with higher growth rates and with more negative skewness (Columns (1) and (3)). The same effect is recorded when I use data on foreign liabilities only, which may be a better proxy for foreign capital (Columns (4) and (6)). I conclude that main results of the paper are broadly consistent across alternative definitions of financial markets liberalization.

\subsubsection{Alternative measures of tail risk and data issues}

In Table 8, I perform another robustness check based on the hypothesis that output skewness may poorly capture tail risk. In particular, while I require that for each country-sector pair in the sample there are at least 10 data points, the higher moments of a distribution can be estimated with a 
substantial bias in small samples (Kendall and Stuart, 1977). I partially counter this concern by replacing my measure of output skewness with the largest negative deviation from the long-term average observed pre- and post-liberalization. The results of this modified version of Model (4) are reported in Columns (1)-(3). The results remain qualitatively unchanged: average output growth increases following liberalization, and so does tail risk, implying that negative skewness is a reasonable proxy for the incidence of tail events of larger magnitude.

In the next six columns of Table 8 , I test the hypothesis that my results may be driven by the fact that the liberalized and non-liberalized countries in the sample contain non-overlapping sets of sectors. I have so far required that each country has at least 10 sectors with at least 20 years of data, but given that there are 21 sectors all in all, it is possible that liberalized countries are a truncated sample of high-growth high-risk industries, biasing the estimates of the baseline model. Therefore, in order to ensure that there is a sufficient overlap, I now require that all countries in the sample contain at least at least 15 (Columns (4)-(6)), and at least 18 (Columns (7)-(9)) industrial sectors. The main results of the paper are not weakened by this robustness procedure.

\subsection{Capital accumulation, productivity, new business creation, and employment}

I next turn to some of the channels through which financial liberalization affects the distribution of growth rates. Previous studies using disaggregated data have found that at the sector level, financial liberalization tends to promote output growth through the growth of existing establishments and through higher capital accumulation (Levchenko et al., 2009; Gupta and Yuan, 2009), and it also stimulates new business creation if adopted by countries with lower barriers to entry (Gupta and Yuan, 2009). I wish to know how these results extend into the higher moments of the distribution of growth rate, and whether the growth effects of liberalization survive a simultaneous equation framework.

The 2010 UNIDO Industrial Statistics 2 Database contains industry data on investment, number of establishments, and employment. I need to construct the capital series from the investment data, 
and the productivity measure from the capital and employment series.

In order to construct the capital series from the investment data in the dataset, I apply the perpetual inventory method proposed by Hall and Jones (1999) and followed by Bonfiglioli (2008) and Levchenko et al. (2009), among others. The initial stock of capital in country $c$ in industry $s$ is estimated as $\frac{I_{c s t}}{g_{c s}+\delta}$, where $g_{c s}$ is the average geometric growth rate of total investment between $t_{0}$ and $t_{0}+10$. A depreciation rate of $\delta=0.06$ is assumed. $t_{0}$ is the first year for which investment data is available in the dataset, for each country-sector pair. Finally, the stock of capital in country $c$ in industry $s$ at time $t$ is computed as $K_{c s t}=(1-\delta) K_{c s t-1}+I_{c s t}$. Next, the TFP data series is constructed by assuming for each industry $s$ in country $c$ a production function $Y_{c s t}=K_{c s t}^{\alpha}\left(A_{c s t} H_{c t} L_{c s t}\right)^{1-\alpha}$, where $Y_{c s t}$ is total output in country $c$ in industry $s$ at time $t, K_{c s t}$ is the stock of physical capital in country $c$ in industry $s$ at time $t, A_{c s t}$ is labour-augmenting productivity in country $c$ in industry $s$ at time $t, L_{c s t}$ is total employment in country $c$ in industry $s$ at time $t$, and $H_{c t}$ is a measure of the average human capital of workers in country $c$ at time t. $H_{c t} L_{c s t}$ is therefore the human capital-augmented labour in country $c$ in industry $s$ at time t. Following Psacharopulos (1994), I define labour-augmenting human capital as a function of years of schooling $\left(e d u c_{c t}\right)$ as $H_{c t}=e^{\phi\left(e d u c_{c t}\right)}$, where $\phi\left(e d u c_{c t}\right)$ is a piecewise linear function with coefficients 0.134 for the first four years of education, 0.101 for the next four years, and 0.068 for all years thereafter. Finally, using data on capital constructed as above, on employment, and on output from the 2010 UNIDO Industrial Statistics 2 Database, as well as data on years of schooling from the Barro and Lee Database, TFP for each industry-country pair is calculated as $A_{c s t}=\frac{Y_{c s t}}{H_{c t} L_{c s t}}\left(\frac{K_{c s t}}{Y_{c s t}}\right)^{\frac{\alpha}{1-\alpha}}$, where the factor share is assumed to be constant in each industry and across countries, and is given the value of one third, which adequately represents national account data for developed countries.

Table 9 reports the estimates from these empirical tests of the modified Model (4). I use all non-liberalized countries as a control group in the tests (the results are robust to a propensity score matching procedure). The evidence is somewhat mixed. In Panel A, Columns (1)-(3), I find that 
financial openness increases the volatility and negative skewness of the process of capital accumulation. The increase in negative skewness relates to the argument in Eichengreen and Lebland (2003) about the link between financial liberalization and banking crises, if liberalizing countries tend to be dominated by industries dependent on external finance. In that sense, my finding somewhat qualifies the result in Galindo et al. (2007) who find that liberalization has a beneficial long-term effect on economic performance by increasing the efficiency with which investment funds are allocated. Alternatively, it could be driven by sudden stops, which, as Rothenberg and Warnock (2011) show, tend to lead to more pronounced slowdowns in GDP than sudden flights.

I find a somewhat similar effect of liberalization on TFP: growth rates increase following liberalization, and so does negative skewness. While the former finding goes somewhat against the results documented in Levchenko et al. (2009) and Gupta and Yuan (2009), who find no robust effect of liberalization on TFP at the sector level, it confirms the findings in Bonfiglioli (2008) and Bekaert et al. (2011) who document a significant increase in aggregate TFP associated with financial openness. My methodology qualifies somewhat this result as well. As Column (5) in Panel A indicates, financial liberalization decreases the volatility of TFP growth, and growth and volatility are positively correlated (Column (4) in Panel A). Hence, while liberalization increases TFP growth directly, it decreases it indirectly through the channel of lower volatility. The sum of the two effects may well amount to zero, reconciling our findings with the prior literature.

In Panel B, I look at the effect of liberalization on establishments and employment. In Columns (1)-(3), I find that financial openness decreases the rate of new business creation directly, but it increases it through the channel of higher volatility, to some degree reconciling my findings with the null results in Levchenko et al. (2009). Liberalization also increases the negative skewness of the process of new business creation. This latter result informs the literature on the effect of the business cycle on business creation. For example, Barlevy (2007) finds that R\&D investment is strongly pro-cyclical. If the entry of new firms follows the development of new technologies, then business cycle-exacerbating financial liberalization would also contribute to a higher negative 
skewness of the distribution of new business.

My final result is that financial liberalization has increased average employment growth, both directly and through the channel of higher volatility, with no significant effect on skewness (Columns (4)-(6)). One possible story, reconciling this result with the result on establishments, would be that liberalization has enabled the emergence of larger and stabler firms. It is also useful to think of this result and the result on new business creation jointly. One strand of literature has maintained the Schumpeterian notion that recessions encourage agents to shift to a more efficient mode of production. A version of this hypothesis is the idea that recessions drive out or "cleanse" the least efficient production arrangements that are no longer profitable (e.g., Caballero and Hammour, 1994; Mortensen and Pissarides, 1994). A related version of this hypothesis, advanced by, for example, Aghion and Saint Paul (1998), argues that recessions encourage agents to engage in activities that contribute to future productivity instead of to current production given that the return to the latter declines in recessions. However, in a more recent study Barlevy (2003) presents evidence that in the presence of credit market frictions, reallocation might direct resources from more efficient to less efficient uses if more efficient production arrangements are also more vulnerable to credit constraints. My results seem to offer stronger evidence to the second theory: if financial liberalization is associated with higher risk, then agents may choose to engage in less profitable employment rather than in more profitable but riskier self-employment.

\subsection{Financial openness, institutions, and economic fluctuations}

There is a growing body of work arguing that various economic developments and institutions should interact with financial liberalization in affecting the distribution of growth rates. For example, democracy and institutions tend to raise economic growth by offering stronger protection of investment, thus both increasing the return to and lowering the cost of entrepreneurship. In general, however, the direct effect on growth may differ from the indirect effect. Mobarak (2005) estimates jointly the effect of democracy on growth and volatility and finds that through the di- 
rect channel, democracy lowers the rate of economic growth, but through the channel of lowering volatility it increases it. Following Acemoglu et al. (2003), I use constraints on the executive as a proxy for the country's level of institutional development.

Domestic financial market development and trade openness have also been argued by the literature to affect output growth and variability (Acemoglu and Zilibotti, 1997; Bekaert et al., 2005; Kose et al., 2006) and so I interact my liberalization variable with empirical proxies for these. Human capital has a positive effect on growth (e.g., Barro, 1991), and so I include a proxy for years of schooling in the interactions. Finally, it is possible that for reasons of unobservable institutional quality, distance to trade centers, and social cohesion, among others, different regions will experience different responses, in terms of growth and risk, to the same event (liberalization). To that end, I include dummies for various regions of the world interacted with the dummy for financial liberalization. I also instrument private credit and institutions using data on legal origin in the spirit of La Porta et al. (1998), who argue that the predetermined component of the country's legal system is a good instrument for concurrent financial and legal development. ${ }^{12}$

The estimates from these empirical tests are reported in Table 10. The evidence suggests that industries experience higher average growth following liberalization in countries with strong institutions (higher constraints on the executive) and in countries with better developed domestic credit markets (Column (1)). In addition, in such countries the distribution of growth rates becomes less negatively skewed following financial liberalization, implying lower risk of abrupt contractions in output at the industry level (Column (3)). To the extent that constraints on the executive are correlated with democracy, this finding is related to the evidence in Rodrik and Wacziarg (2005) that democratization events are associated with a positive effect on economic growth, at least in the short run. The evidence also relates to the finding in Acemoglu et al. (2003) that strong institutions are associated with lower variability of output growth, although my finding is in the dimension of

\footnotetext{
${ }^{12}$ Data on settlers mortality is missing for 31 of the 53 countries in the sample, and so while in robustness exercises the main message of Table 10 is not altered by using settlers mortality to instrument for institutions, as in Acemoglu et al. (2003), I do not report these results here.
} 
the skewness, not in the dimension of volatility. Finally, I also find that Latin American countries benefited relatively more from liberalization than Europe and North America (the control group) in terms of both higher growth and lower skewness. These findings are related to recent evidence pointing to the fact that after financial liberalization Latin American stock markets have become less volatile (Edwards et al., 2003). Finally, there is some evidence that financially open economies tend to have a more volatile output growth if they are also open to trade (Column (2)), relating to recent evidence on the positive effect of trade openness on aggregate volatility (e.g., Di Giovanni and Levcnehko, 2009).

\subsection{Financial openness and skewness: Aggregate data evidence}

The main purpose of this paper is to identify the impact of financial openness on the distribution of output growth, not to address the welfare implications of this process, and industry-level data is better suited than country-level data for this purpose. Nevertheless, the question whether the growth-skewness pattern I have uncovered holds in the aggregate data, is fully warranted. In particular, while higher industry growth implies higher aggregate growth by a simple mathematical identity, it is not immediately clear whether a more negative industry skewness should imply a more negative aggregate skewness. For example, while Ramey and Ramey (1995) show that more volatile countries tend to have lower long-term growth, Imbs (2007) argues that the opposite pattern holds in disaggregated data where high-growth industries command higher investment and tend to be more volatile. This sectoral pattern is masked by aggregation as the country specific component of aggregate variance, which tends to be detrimental to long-term growth, dominates. How industrylevel output skewness aggregates into total output skewness is thus an empirical question which can reveal whether financial openness may potentially be imposing welfare costs associated with large and rare macroeconomic contractions a la Barro (2006, 2009).

To formally test this, in Table 11 I use data from the Penn Tables on total output over for the same sample of countries and sample period as in the previous empirical tests. Identification is now 
hindered by the fact that I can no longer extract within-country cross-industry components, but I do control for the standard determinants of growth and volatility (e.g., Barro, 1991; Bekaert et al., 2006), like financial and economic development, trade openness, government spending, various aspects of human capital (education, life expectancy, population growth), and macroeconomic stability (inflation). I also control for the quality of institutions, using the measure of constraints on executives from Polity IV, but data are missing for 2 of the 53 countries and so I run a separate regression using that variable.

The estimates strongly imply that financial openness increases the negative skewness of GDP growth. Numerically, in the post-liberalization period, the skewness of the distribution of growth rates in a financially open country is lower by 0.54 of a sample standard deviation relative to a nonopen country. There is (weak) evidence that larger financial markets, high population growth, and larger governments have an independent negative effect on skewness. Thus - while mindful of all caveats related to the use of cross-country data for identification purposes - the evidence tentatively suggests that when it comes to the negative effect of financial openness on output skewness, there is no averaging away of sector-specific developments, as in the case of the volatility.

Figure 1 illustrates this result by comparing the output growth pattern of Argentina and Panama. These two countries are similar in terms of per capita wealth, are a part of the same economic area, and exhibit similar trade patterns. By the definition of financial liberalization used in the paper, Argentina became fully open in 1991. According to the same criteria, Panama is not. Figure 1 indicates that Argentina grew at a rate almost four times higher after 1991 (2.6\% vs. 0.7\%), while annual growth rates in Panama declined somewhat after 1991, from $3.8 \%$ to $2.9 \%$. Aggregate volatility declined in Panama while it remained steady in Argentina. Finally, while the distribution of growth rates became more positively skewed in Panama, it went from symmetric to negatively skewed in Argentina (-0.666 post-liberalization vs. -0.118 pre-liberalization). Thus, relative to non-liberalized Panama, liberalized Argentina experienced higher growth, and its growth distribution became more negatively skewed indicating the incidence of a large and abrupt 
macroeconomic contraction. ${ }^{13}$

\section{Conclusion}

In this paper, I examine the effect of financial openness on the distribution of growth rates over the business cycle. The literature has so far focused on output growth and volatility, pointing to mixed effects of financial liberalization in the dimension of volatility (see Kose et al., 2006, for a survey) and to a mostly positive effect in the dimension of growth, especially in the case of stock market liberalization (Bekaert et al., 2005; Gupta and Yuan, 2009). However, the first two moments of growth do not exhaust the welfare implications of financial openness. In particular, the same increase in volatility could be driven by one large macroeconomic contraction, or by a series of small symmetric deviations from a relatively stable growth path. In the latter case, a larger government would insure the additional output volatility away (Rodrik, 1998b), and even with no insurance the welfare cost of higher volatility would be small (Lucas, 1987). In the former case, however, the government sector could be unable to provide adequate insurance, and so a large and rare macroeconomic contraction could impose non-negligible welfare costs on economic agents as in Barro (2006, 2009).

To address this point, I use output data on 53 countries over 45 years to study the impact of financial liberalization on output growth, volatility, and skewness. The skewness of the distribution of output growth captures the asymmetric variability of the growth process and is thus more closely related to the concept of disaster risk than the volatility. I also estimate the effect of liberalization on the first three moments of growth jointly, which allows me to separate the direct from the indirect effect of liberalization. I rely on industry-level data in order to identify a causal link between openness and the pattern of output fluctuations.

The data strongly suggests that financial openness is associated with higher output growth, but also with higher variability of output growth, more so in the sense of negative skewness than in

\footnotetext{
${ }^{13}$ Argentina's real GDP declined by $20 \%$ between 1998 and 2002.
} 
the sense of higher volatility. These results are remarkably robust to a wide variety of alternative tests, including accounting for the strategic choice associated with liberalization, controlling for the channels through which concurrent policy reforms and macroeconomic developments affect the rate and the variability of the growth process, and alternating between de jure and de facto measures of openness. Regarding the specific channels, the increase in negative skewness appears to be driven by a more left-skewed distribution of growth rates of capital, TFP, and new business creation. I also find that the direct effect of financial openness on skewness is somewhat muted by the indirect effect through the channel of higher growth. Finally, countries with deeper financial markets and with better institutions seem to benefit more from financial liberalization, both in terms of higher growth and in terms of lower probability of large and rare contractions.

While the evidence suggests that for sufficiently disaggregated data, financial openness increases the probability of large, abrupt, and rare contractions in output, this need not hold in the aggregate. Imbs (2007) shows that while high-growth activities tend to be more volatile, in the aggregate data a component of aggregate volatility dominates which correlates negatively with growth, and hence an increase in sectoral volatility is not inconsistent with a decrease in aggregate volatility. In the last part of the paper, I provide evidence that financial openness is associated with a more negatively skewed distribution not just of sectoral growth rates, but of aggregate growth rates as well. While tests using country-level data are traditionally prone to conceptual and econometric problems, the evidence tentatively suggests that there is no averaging away of sector-specific developments, as in the case of the volatility. What are the welfare consequences of this combined increase in growth and in negative skewness would, of course, require a fully specified growth model, as well as a robust empirical test of the role of the government sector in insuring away not just excess volatility, but also excess negative skewness. Such an investigation is beyond this paper's scope. 


\section{References}

[1] Acemoglu, D., and F. Zilibotti, 1997. Was Prometheus unbound by chance? Risk, diversification, and growth. Journal of Political Economy 105, 709-751.

[2] Acemoglu, D., Johnson, S., Robinson, J., and Y. Thaicharoen, 2003. Institutional causes, macroeconomic symptoms: volatility, crises and growth. Journal of Monetary Economics 50, $49-123$.

[3] Aghion, P., and G. Saint Paul, 1998. Virtues of bad times: Interaction between productivity growth and economic fluctuations. Macroeconomic Dynamics 2, 322-344.

[4] Aghion, P., and A. Banerjee, 2005. Volatility and Growth. Oxford University Papers: USA.

[5] Aghion, P., Angeletos, M., Banerjee, A., and K. Manova, 2010. Volatility and growth: Credit constraints and the composition of investment. Journal of Monetary Economics 57, 246-265.

[6] Barlevy, G., 2003. Credit market frictions and the allocation of resources over the business cycle. Journal of Monetary Economics 50, 1795-1818.

[7] Barlevy, G., 2007. On the cyclicality of research and development. American Economic Review 97, 1131-1164.

[8] Barro, R. 1991. Economic growth in a cross section of countries. Quarterly Journal of Economics 106, 407-443.

[9] Barro, R., 2006. Rare disasters and asset markets in the twentieth century. Quarterly Journal of Economics 121, 823-866.

[10] Barro, R., 2009. Rare disasters, asset prices, and welfare costs. American Economic Review 99, 243-264.

[11] Beck, T., Levine, R., and N. Loayza, 2000. Financial intermediation and growth: Causality and causes. Journal of Monetary Economics 46, 31-77. 
[12] Beck, T., Demirgüç-Kunt, A., and R. Levine, 2010. Financial institutions and markets across countries and over time: The updated financial development and structure database. World Bank Economic Review 24, 77-92.

[13] Bekaert, G., and C. Harvey, 2000. Foreign speculation and emerging equity markets. Journal of Finance 55, 565-613.

[14] Bekaert, G., Harvey, C., and C. Lundblad, 2002. Growth volatility and equity market liberalization. Unpublished working paper, Duke University.

[15] Bekaert, G., Harvey, C., and C. Lundblad, 2005. Does financial liberalization spur growth? Journal of Financial Economics 77, 3-55.

[16] Bekaert, G., Harvey, C., and C. Lundblad, 2006. Growth volatility and financial liberalization. Journal of International Money and Finance 25, 370-403.

[17] Bekaert, G., Harvey, C., and C. Lundblad, 2011. Financial openness and productivity. World Development 39, 1-19.

[18] Bekaert, G., Harvey, C., Lundblad, C., and S. Siegel, 2007. Global growth opportunities and market integration. Journal of Finance 62, 1081-1137.

[19] Bonfiglioli, A., 2008. Financial integration, productivity, and capital accumulation. Journal of International Economics 76, 337-355.

[20] Caballero, R., and M. Hammour, 1994. The cleansing effect of recessions. American Economic Review 84, 1350-1368.

[21] Caballero, R., and A. Krishnamurty, 2001. International and domestic collateral constraints in a model of emerging market crises. Journal of Monetary Economics 48, 513-548.

[22] Di Giovanni, J., and A. Levchenko, 2009. Trade openness and volatility. The Review of Economics and Statistics 91, 558-585. 
[23] Easterly, W., Islam, R., and J. Stiglitz, 2001. Shaken and stirred: Explaining growth volatility. In B. Pleskovic and N. Stern (Eds.), Proceeding of the Annual Bank Conference on Development Economics, pp. 191-211 (Washington, DC: World Bank).

[24] Edwards, S., 2001. Capital mobility and economic performance: Are emerging economies different? In: Siebert, H. (Ed.), The World's New Financial Landscape: Challenges for Economic Policy, pp. 219-244. Springer, Berlin.

[25] Edwards, S., Biscarri, J., and F. Perez de Gracia, 2003. Stock market cycles, financial liberalization and volatility. Journal of International Money and Finance 22, 925-955.

[26] Eichengreen, B., and D. Leblang, 2003. Capital account liberalization and growth: Was Mr. Mahathir right? International Journal of Finance and Economics 8, 205-224.

[27] Epstein, L., and S. Zin, 1989. Substitution, risk aversion, and the temporal behavior of consumption and asset returns: A theoretical framework. Econometrica 57, 937-969.

[28] Fisman, R., and I. Love, 2007. Financial dependence and growth revisited. Journal of the European Economic Association 5, 470-479.

[29] Gabaix, X., 2008. Variable rare disasters: A tractable theory of ten puzzles in macro-finance. American Economic Review: Papers 8 Proceedings 98, 64-67.

[30] Glick, R., Guo, X., and M. Hutchinson, 2006. Currency crises, capital account liberalization, and selection bias. The Review of Economics and Statistics 88, 698-714.

[31] Gourio, F., 2008. Disasters and recoveries. American Economic Review: Papers 6 Proceedings 98, 68-73.

[32] Gupta, N., and K. Yuan, 2009. On the growth effect of stock market liberalizations. Review of Financial Studies 22, 4715-4752. 
[33] Hall, R., and C. Jones, 1999. Why do some countries produce so much more output per worker than others? Quarterly Journal of Economics 114, 83-116.

[34] Henry, P., 2000. Do stock market liberalizations cause investment booms? Journal of Financial Economics 58, 301-334.

[35] Henry, P., 2007. Capital account liberalization: Theory, evidence, and speculation. Journal of Economic Literature 45, 887-935.

[36] Heston, A., Summers, R., and B. Aten, 2002. Penn World Table Version 6.1. Center for International Comparisons at the University of Pennsylvania (CICUP).

[37] Imbs, J., 2007. Growth and volatility. Journal of Monetary Economics 54, 1848-1862.

[38] Kaminsky, G., and S. Schmukler, 2008. Short-run pain, long-run gain: The effects of financial liberalization. Review of Finance 12, 253-292.

[39] Kendall, M., and A. Stuart, 1977. The advanced theory of statistics. New York, Macmillan.

[40] Kose, A., Prasad, E., Rogoff, K., and S.-J. Wei, 2003. Effects of financial globalization on developing countries: Some empirical evidence. International Monetary Fund Occasional Paper 220 .

[41] Kose, A., Prasad, E., Rogoff, K., and S.-J. Wei, 2006. Financial globalization, a reappraisal. IMF Working Paper 06/189.

[42] La Porta, R., Lopez-de-Silanes, F., Shleifer, A., and R. Vishny, 1998. Law and finance. Journal of Political Economy 106, 1113-1155.

[43] Lane, P., and G. M. Milesi-Ferretti, 2007. The external wealth of nations mark II: Revised and extended estimates of foreign assets and liabilities, 1970-2004. Journal of International Economics 73, 223-250. 
[44] Levchenko, A., Ranciere, R., and M. Thoenig, 2009. Growth and risk at the industry level: The real effects of financial liberalization. Journal of Development Economics 89, 210-222.

[45] Love, I., 2003. Financial development and financial constraints: International evidence from the structural investment model. Review of Financial Studies 16, 765-791.

[46] Lucas, R., 1987. Models of Business Cycles. New York: Basil Blackwell.

[47] Lundberg, M., and L. Squire, 2003. The simultaneous evolution of growth and inequality. Economic Journal 113, 326-344.

[48] Mobarak, M., 2005. Democracy, volatility, and economic development. The Review of Economics and Statistics 87, 348-361.

[49] Mortensen, D., and C. Pissarides, 1994. Job creation and job destruction in the theory of unemployment. Review of Economic Studies 61, 397-415.

[50] Persson, T., 2001. Currency unions and trade: How large is the treatment effect? Economic Policy 16, 435-448.

[51] Psacharopulos, G., 1994. Returns to investment in education: A global update. World Development 22, 1325-1343.

[52] Quinn, D., and M. Toyoda, 2008. Does capital account liberalization lead to growth? Review of Financial Studies 21, 1403-1449.

[53] Raddatz, C., 2006. Liquidity needs and vulnerability to financial underdevelopment. Journal of Financial Economics 80, 677-722.

[54] Rajan, R., and L. Zingales, 1998. Financial dependence and growth. American Economic Review 88, 559-586.

[55] Ramey, G., and V. Ramey, 1995. Cross-country evidence on the link between volatility and growth. American Economic Review 85, 1138-1151. 
[56] Rancière, R., Tornell, A., and F. Westermann, 2008. Systemic crises and growth. Quarterly Journal of Economics 123, 359-406.

[57] Rodrik, D., 1998a. Who needs capital account convertibility? In: P. Kennon (Ed.), Princeton Essays in International Finance, No. 207.

[58] Rodrik, D., 1998b. Why do more open economies have bigger governments? Journal of Political Economy 106, 997-1032.

[59] Rodrik, D., and R. Wacziarg, 2005. Do democratic transitions produce bad economic outcomes? American Economic Review 95, 50-55.

[60] Rosenbaum, P., and D. Rubin, 1983. The central role of the propensity score in observational studies for causal effects. Biometrika 70, 41-55.

[61] Rothenberg, A., and F. Warnock, 2011. Sudden flight and true sudden stops. NBER Working Paper No. 12726.

[62] Stiglitz, J., 2000. Capital market liberalization, economic growth and instability. World Development $28,1075-1086$.

[63] Weil, P., 1990. Nonexpected utility in macroeconomics. Quarterly Journal of Economics 105, $29-42$. 

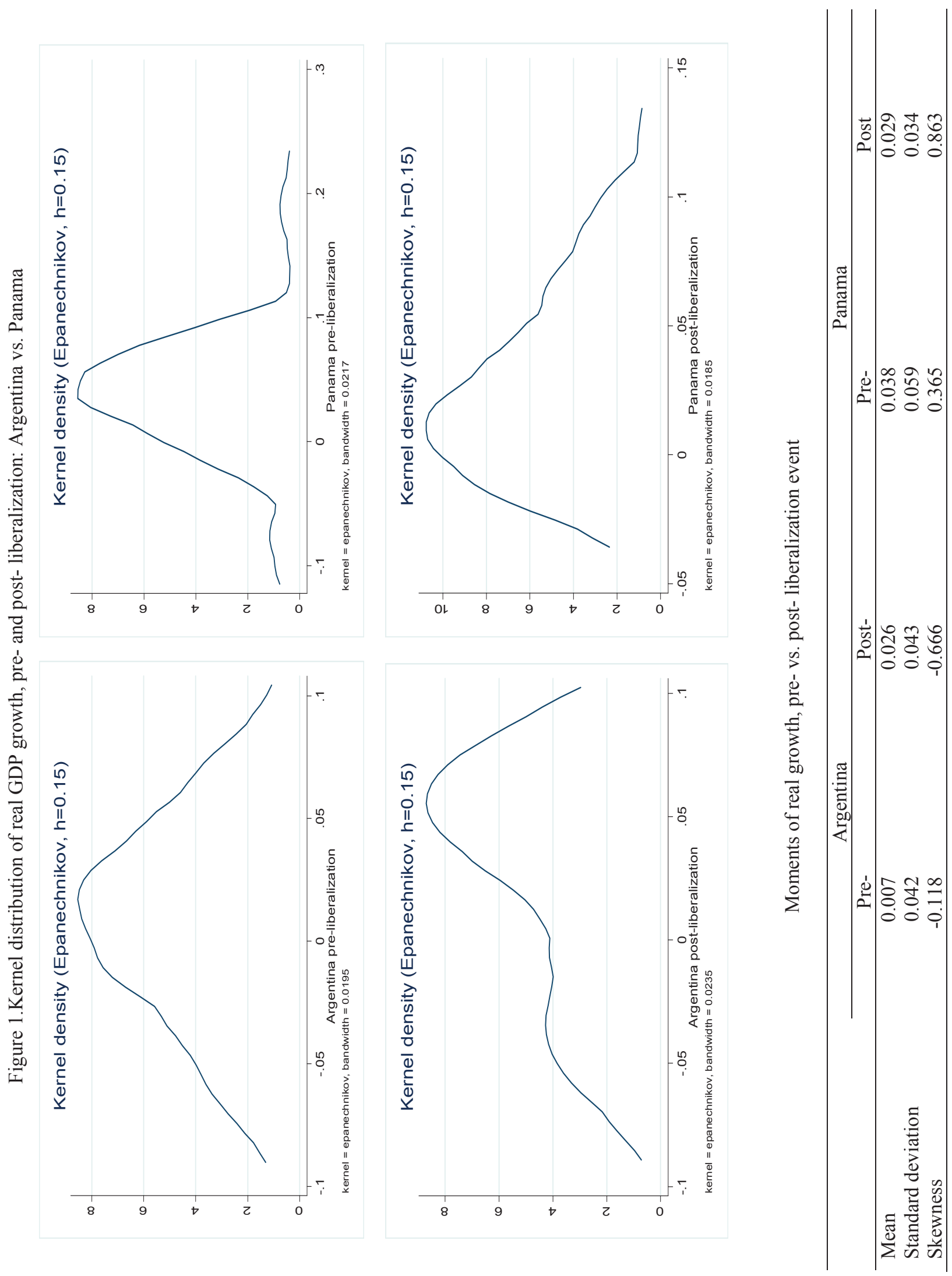


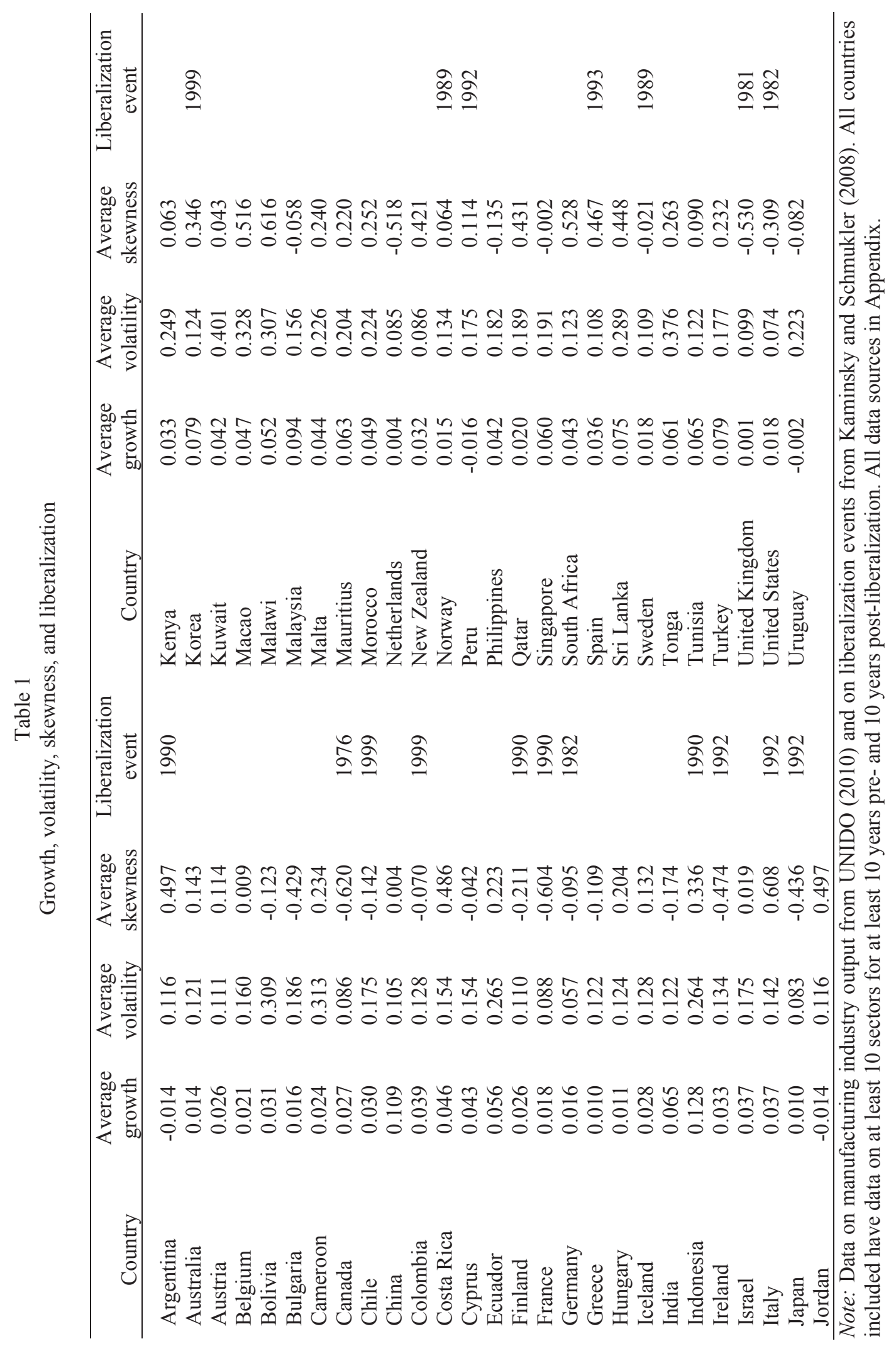


Table 2

Country characteristics

\begin{tabular}{|c|c|c|c|c|c|}
\hline Country & $\begin{array}{l}\text { Log GDP } \\
\text { per capita }\end{array}$ & $\begin{array}{c}\text { Private credit } \\
\text { / GDP }\end{array}$ & $\begin{array}{c}\text { Trade } \\
\text { openness }\end{array}$ & $\begin{array}{c}\text { Human } \\
\text { capital }\end{array}$ & $\begin{array}{c}\text { Constraints on } \\
\text { executive }\end{array}$ \\
\hline Argentina & 9.30 & 0.12 & 0.17 & 67.96 & 2.15 \\
\hline Australia & 9.83 & 0.39 & 0.22 & 87.42 & 4.20 \\
\hline Austria & 9.82 & 0.61 & 0.48 & 93.42 & 3.93 \\
\hline Belgium & 9.78 & 0.24 & 0.97 & 93.02 & 5.50 \\
\hline Bolivia & 8.05 & 0.14 & 0.44 & 67.74 & 2.06 \\
\hline Bulgaria & 8.49 & 0.09 & 0.81 & 85.86 & 1.00 \\
\hline Cameroon & 7.85 & 0.11 & 0.29 & 11.57 & 1.00 \\
\hline Canada & 9.70 & 0.32 & 0.37 & 94.64 & 4.00 \\
\hline Chile & 9.00 & 0.34 & 0.38 & 84.53 & 2.13 \\
\hline China & 7.13 & 0.26 & 0.29 & 88.32 & 1.00 \\
\hline Colombia & 8.54 & 0.21 & 0.25 & 57.94 & 2.33 \\
\hline Costa Rica & 8.87 & 0.13 & 0.44 & 37.71 & 3.00 \\
\hline Cyprus & 9.02 & 0.70 & 0.69 & 86.79 & 3.00 \\
\hline Ecuador & 8.38 & 0.13 & 0.41 & 49.48 & 2.81 \\
\hline Finland & 9.67 & 0.44 & 0.35 & 95.09 & 4.43 \\
\hline France & 9.76 & 0.52 & 0.24 & 91.85 & 6.80 \\
\hline Germany & 9.79 & 0.69 & 0.29 & 97.46 & 6.56 \\
\hline Greece & 9.55 & 0.20 & 0.23 & 82.44 & 3.00 \\
\hline Hungary & 9.21 & 0.19 & 0.32 & 87.21 & 1.00 \\
\hline Iceland & 9.92 & 0.32 & 0.61 & 86.16 & 4.06 \\
\hline India & 7.24 & 0.15 & 0.16 & 56.78 & 4.06 \\
\hline Indonesia & 7.66 & 0.13 & 0.54 & 47.99 & 1.00 \\
\hline Ireland & 9.41 & 0.47 & 0.52 & 84.35 & 5.41 \\
\hline Israel & 9.51 & 0.41 & 0.52 & 88.20 & 3.56 \\
\hline Italy & 9.73 & 0.51 & 0.32 & 91.05 & 4.73 \\
\hline Japan & 9.75 & 0.85 & 0.13 & 99.51 & 3.47 \\
\hline Jordan & 8.60 & 0.46 & 0.83 & 79.74 & 1.00 \\
\hline Kenya & 7.54 & 0.18 & 0.53 & 38.13 & 1.00 \\
\hline Korea & 8.92 & 0.74 & 0.26 & 89.50 & 2.96 \\
\hline Kuwait & 10.83 & 0.16 & 0.90 & 78.51 & 1.00 \\
\hline Macao & 9.71 & 0.51 & 1.43 & 67.73 & --- \\
\hline Malawi & 6.74 & 0.07 & 0.75 & 28.19 & 1.00 \\
\hline Malaysia & 8.62 & 0.43 & 0.93 & 64.14 & 3.25 \\
\hline Malta & 9.01 & 0.46 & 2.01 & 85.13 & 3.00 \\
\hline Mauritius & 8.80 & 0.26 & 1.19 & 71.62 & 4.15 \\
\hline Morocco & 8.30 & 0.22 & 0.40 & 32.67 & 1.00 \\
\hline Netherlands & 9.86 & 0.69 & 0.60 & 87.14 & 4.06 \\
\hline New Zealand & 9.67 & 0.54 & 0.32 & 90.49 & 3.00 \\
\hline Norway & 9.96 & 0.69 & 0.55 & 94.79 & 3.64 \\
\hline Peru & 8.56 & 0.06 & 0.27 & 67.75 & 2.94 \\
\hline Philippines & 8.02 & 0.19 & 0.53 & 53.25 & 1.50 \\
\hline Qatar & 11.09 & 0.26 & 0.93 & 74.45 & 1.00 \\
\hline Singapore & 9.33 & 0.64 & 2.93 & 77.32 & 2.00 \\
\hline South Africa & 8.93 & 0.39 & 0.49 & 66.67 & 1.75 \\
\hline Spain & 9.54 & 0.67 & 0.19 & 87.28 & 3.28 \\
\hline Sri Lanka & 7.72 & 0.09 & 0.73 & 56.12 & 3.00 \\
\hline Sweden & 9.81 & 0.60 & 0.42 & 96.43 & 3.36 \\
\hline
\end{tabular}




\begin{tabular}{llllll} 
Tonga & 8.37 & 0.19 & 0.90 & 71.78 & --- \\
Tunisia & 8.18 & 0.52 & 1.08 & 57.21 & 1.00 \\
Turkey & 8.29 & 0.12 & 0.15 & 57.94 & 3.75 \\
United Kingdom & 9.62 & 0.24 & 0.28 & 94.98 & 4.50 \\
United States & 9.95 & 0.85 & 0.10 & 87.27 & 4.67 \\
Uruguay & 8.96 & 0.18 & 0.29 & 67.74 & 2.44 \\
\hline
\end{tabular}

Note: The Table reports summary statistics from country-specific control variables. 'Log GDP per capita' is the logarithm of average GDP per capita in the period before and after a liberalization event. 'Private credit/GDP' is the ratio of credit to the private sector to GDP. 'Trade openness' is the average degree of openness to trade in the 10 years before and after a liberalization event. 'Human capital' is the ratio of secondary school enrollment to total enrollment. 'Constraints on the executive' is an index of checks and balances on the executive branch of government. All data sources in Appendix. 
Table 3

Industry characteristics

\begin{tabular}{|c|c|c|c|c|c|}
\hline Two-Digit ISIC Sector & $\begin{array}{c}\text { External } \\
\text { dependence }\end{array}$ & $\begin{array}{c}\text { Growth } \\
\text { opportunities }\end{array}$ & $\begin{array}{c}\text { Liquidity } \\
\text { needs }\end{array}$ & $\begin{array}{c}\text { Exports/ } \\
\text { Output }\end{array}$ & $\begin{array}{r}\text { Imports/ } \\
\text { Output }\end{array}$ \\
\hline 15. Food and beverages & -0.118 & 0.056 & 0.10 & 0.168 & 0.239 \\
\hline 16. Tobacco manufacturing & -0.459 & 0.045 & 0.24 & 0.158 & 0.591 \\
\hline 17. Textile mills products & -0.067 & 0.072 & 0.16 & 0.209 & 1.127 \\
\hline 18. Wearing apparel and fur & -0.489 & 0.062 & 0.20 & 1.047 & 0.797 \\
\hline 19. Leather and leather products & -0.996 & 0.027 & 0.245 & 0.654 & 2.057 \\
\hline 20. Wood products & 0.058 & 0.079 & 0.15 & 1.499 & 8.130 \\
\hline 21. Paper and allied products & -0.052 & 0.074 & 0.11 & 0.184 & 0.729 \\
\hline 22. Printing and publishing & -0.120 & 0.089 & 0.08 & 0.065 & 0.173 \\
\hline 23. Petroleum and coal products & -0.065 & 0.009 & 0.105 & 0.201 & 1.037 \\
\hline 24. Chemicals and allied products & 0.306 & 0.031 & 0.14 & 0.413 & 1.417 \\
\hline 25. Rubber and plastic products & -0.031 & 0.052 & 0.14 & 0.276 & 1.073 \\
\hline 26. Stone, clay, glass and concrete & 0.083 & 0.040 & 0.16 & 0.420 & 1.486 \\
\hline 27. Primary metals & 0.083 & 0.040 & 0.155 & 0.861 & 1.624 \\
\hline 28. Fabricated metal products & -0.067 & 0.043 & 0.18 & 0.183 & 0.577 \\
\hline 29. Industrial machinery and equipment & 0.058 & 0.030 & 0.21 & 3.878 & 12.188 \\
\hline 30. Office, accounting, and computing & 0.058 & 0.030 & 0.21 & 0.484 & 2.205 \\
\hline 31. Electrical and electronic equipment & 0.441 & 0.044 & 0.21 & 0.484 & 2.205 \\
\hline 32. Radio, television, and communications & 0.244 & 0.044 & 0.21 & 0.484 & 2.205 \\
\hline 33. Medical, precision, and optical instruments & 0.473 & 0.026 & 0.21 & 0.484 & 2.205 \\
\hline 34. Other transportation equipment & 0.129 & 0.056 & 0.15 & 1.499 & 8.130 \\
\hline 35. Furniture; miscellaneous manufacturing & 0.031 & 0.049 & 0.21 & 1.035 & 4.941 \\
\hline
\end{tabular}

Note: The Table reports summary statistics from country-specific control variables. 'External dependence' is the sector's median value of capital expenditures minus cash flows divided by capital expenditures. 'Growth opportunities' is the sector's median sales growth. 'Liquidity needs' is the sector's median value of total inventories divided by total sales. 'Exports/Output' is average exports in a particular sector divided by output in a particular sector. 'Imports/Output' is average imports in a particular sector divided by output in a particular sector. All data for mature Compustat firms (data sources in Appendix). 


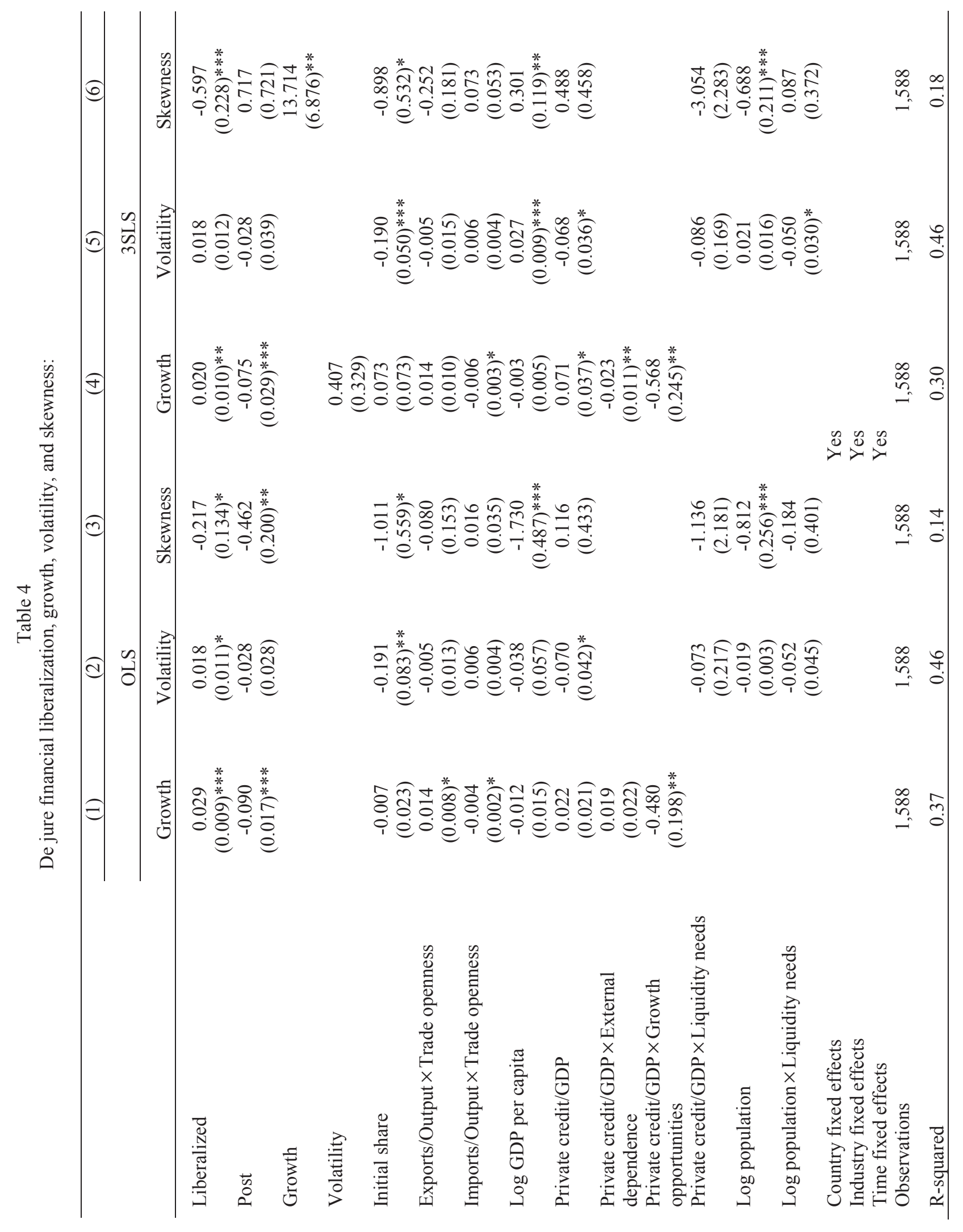




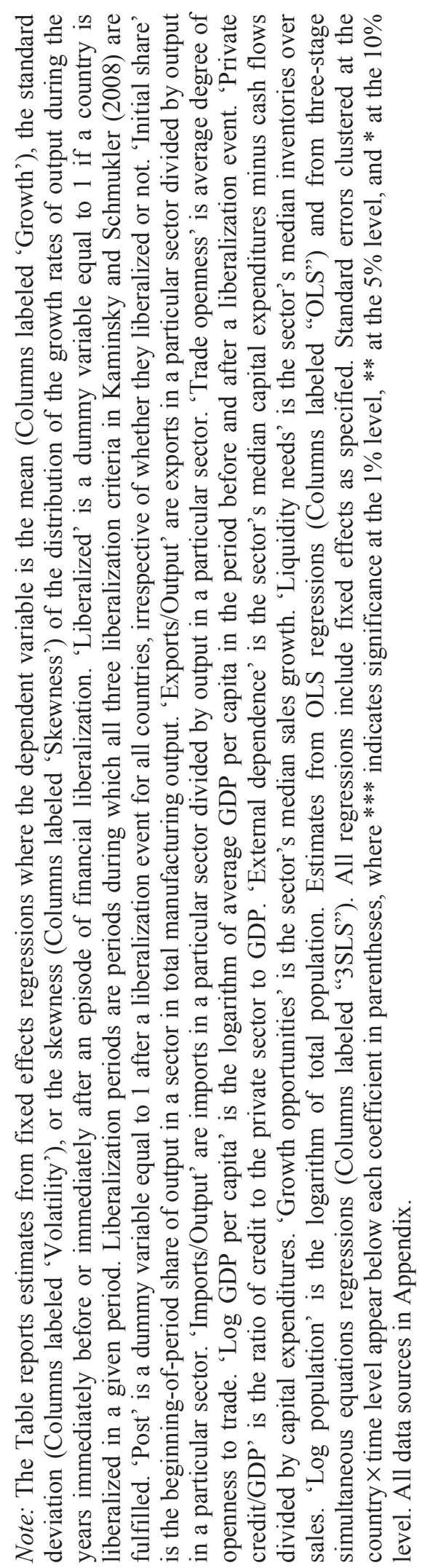




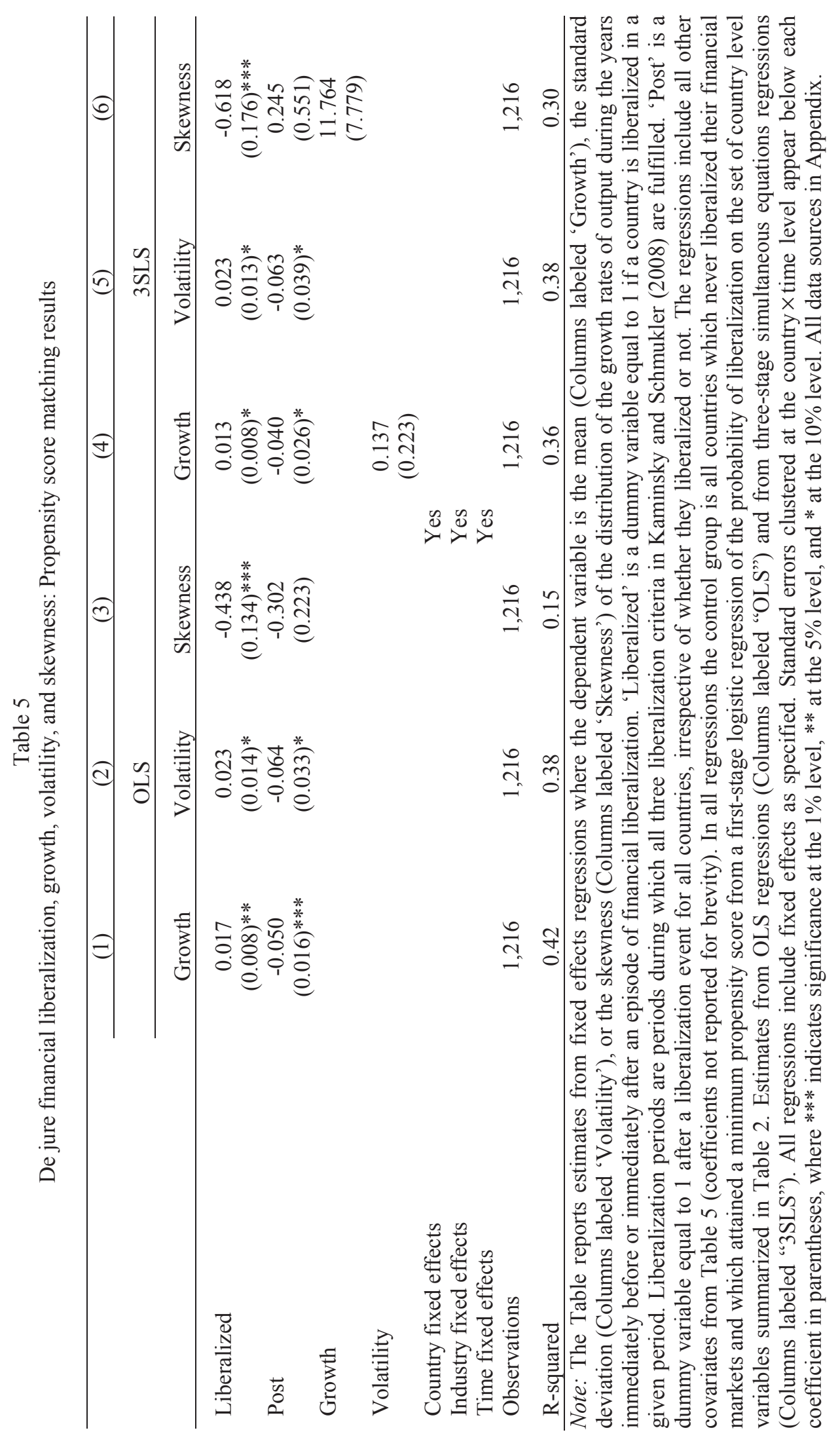




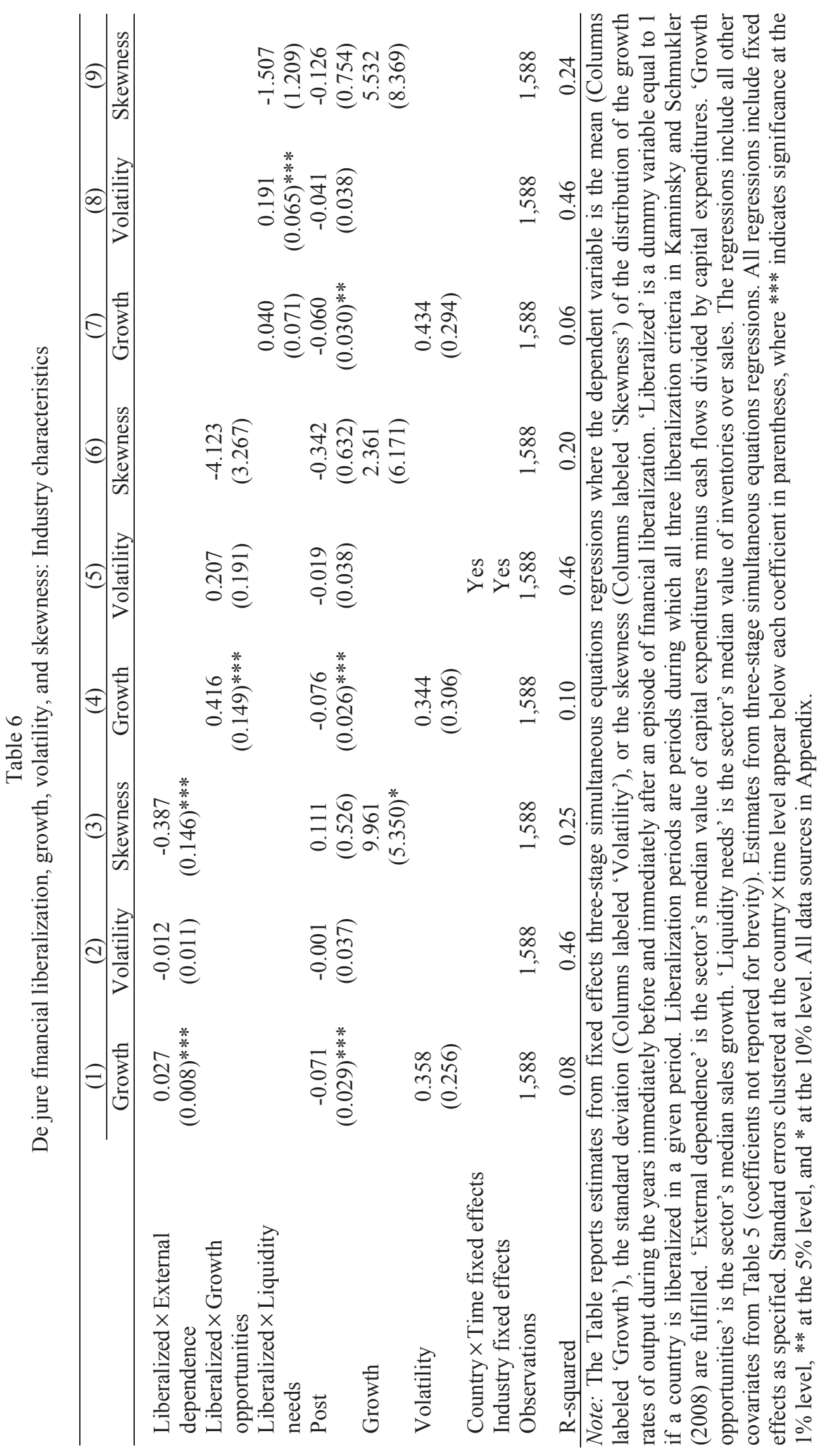




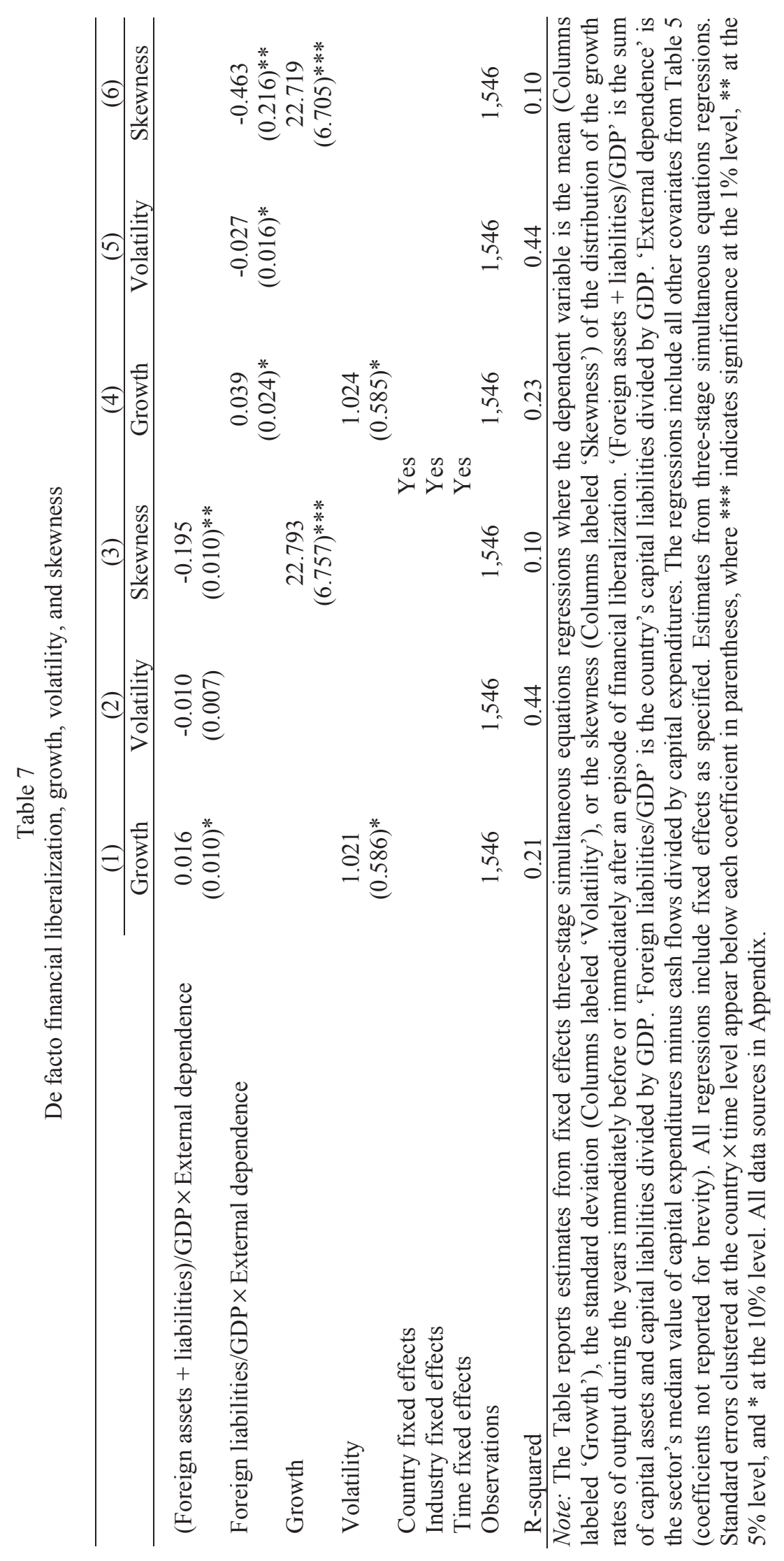




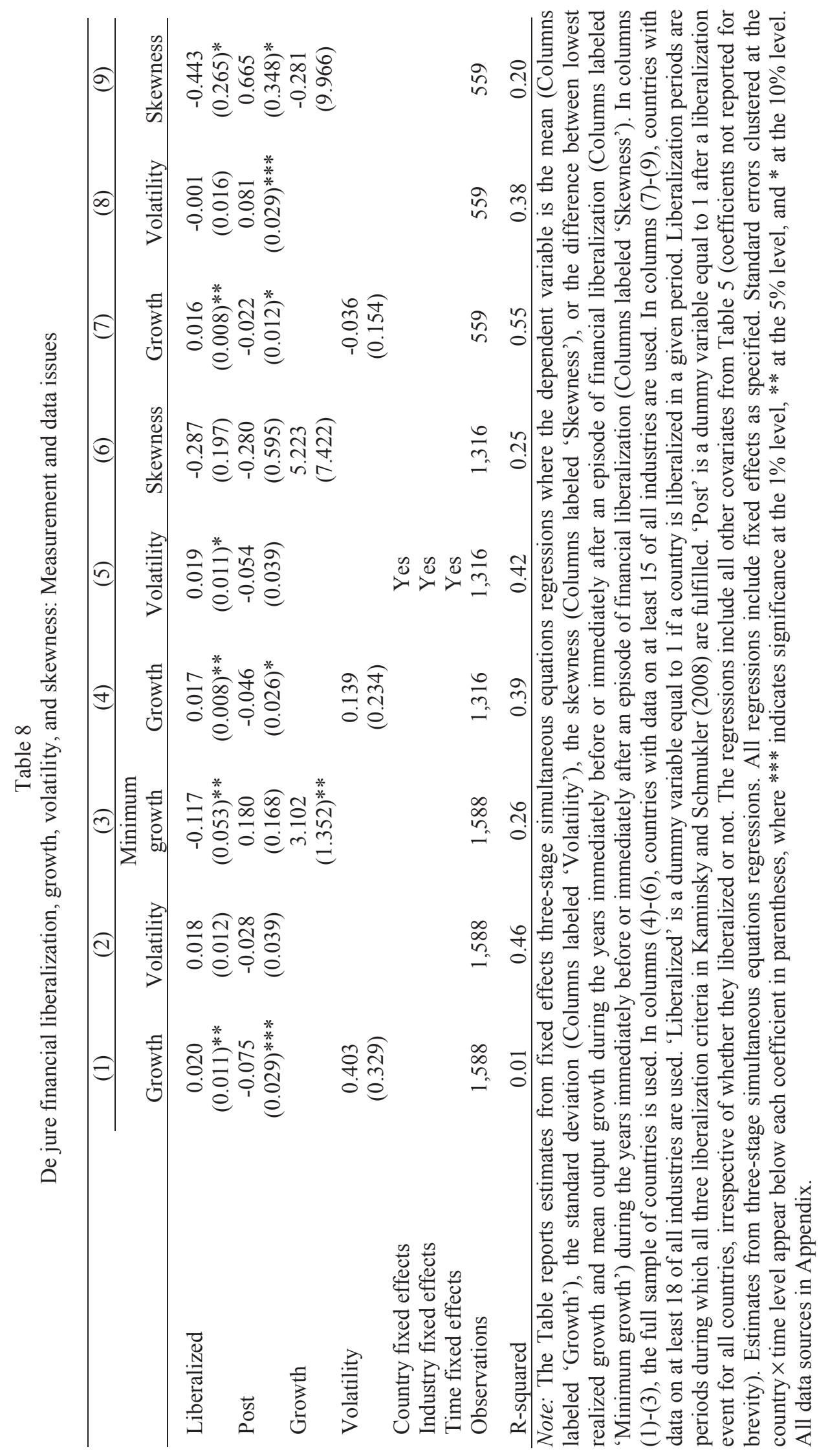




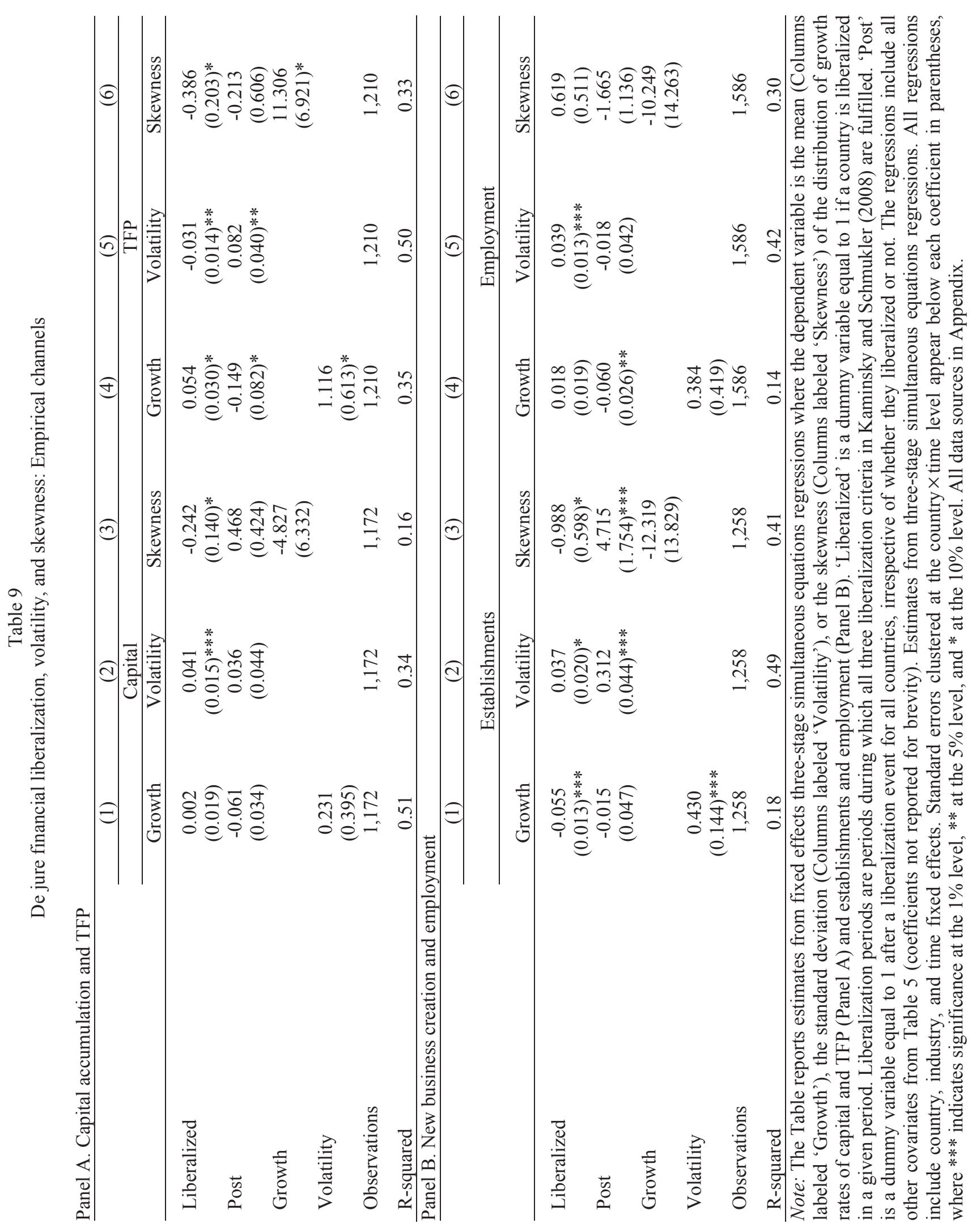




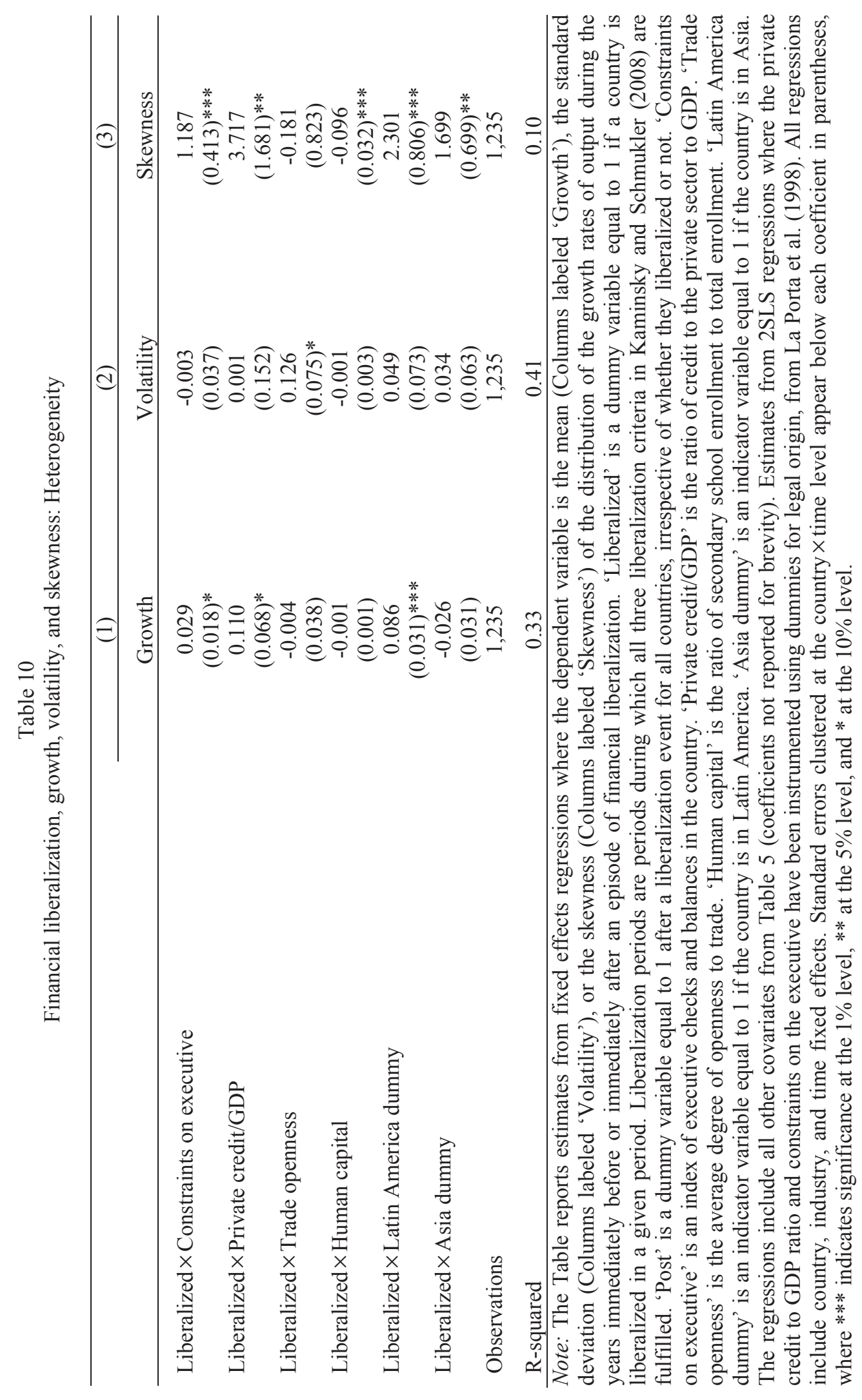




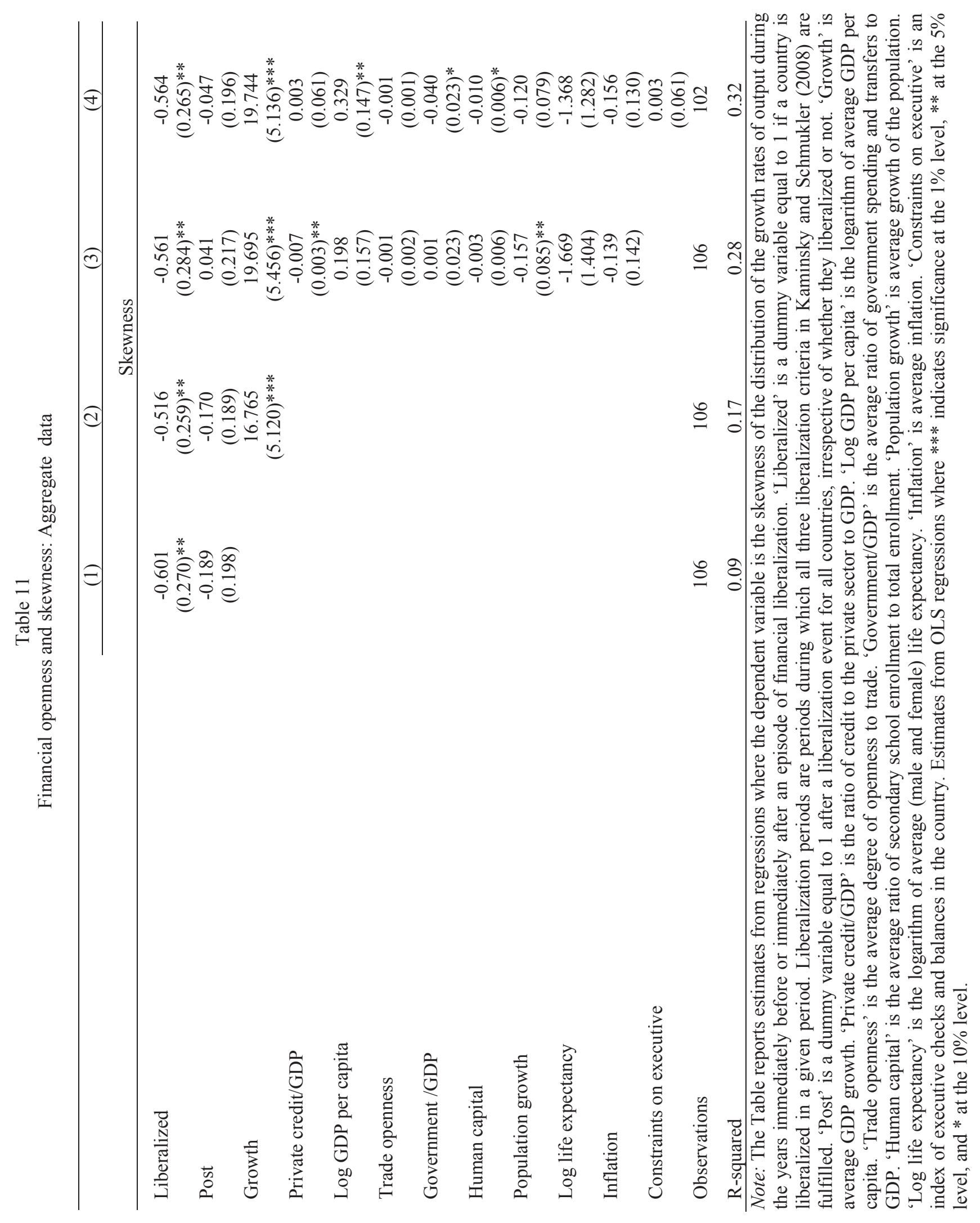


Output

Liberalized

Post

Initial share

Minimum growth

Log population

Population growth

GDP per capita

GDP growth

Log GDP per capita

Trade openness

Human capital

Years of schooling

Life expectancy

Inflation

Constraints on executive

Private credit/GDP
Total output in a particular industry in a particular country in a particular year, in constant US dollars. Source: INDSTAT 2010 Rev. 3.

Dummy variable equal to 1 following the year in which the country attains a liberalization status on all three liberalization dimensions - credit markets, stock markets, and capital controls - for countries which liberalized. Source: Kaminsky and Schmukler (2008).

Dummy variable equal to 1 following the year in which the country attains a liberalization status on all three liberalization dimensions - credit markets, stock markets, and capital controls - for countries which liberalized. For countries which did not, it equals 1 after the mean liberalization year in the sample. Source: Kaminsky and Schmukler (2008).

The industry's share of output out of total manufacturing output in this country for a particular year. Source: INDSTAT 2010 Rev. 3.

Difference between minimum growth experienced during the pre- or post-liberalization period and the average growth experience during that period, for each industry. Source: INDSTAT 2010 Rev. 3.

Average logarithm of the total population in the respective country. Source: Penn Tables.

Average growth in the total population over the previous year. Source: Penn Tables and author's calculations.

Average of total GDP divided by the population. Source: Penn Tables.

Average growth in GDP per capita over the previous year. Source: Penn Tables.

Logarithm of average GDP per capita for the pre- and post-liberalization period. Source: Penn Tables.

Average index of the country's realized openness to trade. Source: Penn Tables.

Average ratio of secondary school enrollment to total enrollment. Source: World Bank Development Indicators.

Average years of schooling per person (male and female) in the country. Source: Barro and Lee Database.

Average life expectancy at birth. Source: WB Development Indicators.

Average inflation in the respective country over the previous year. Source: WB Development Indicators.

Average index of executive checks and balances on the executive branch of government. Source: Polity IV.

Average value of total credits by financial intermediaries to the private sector in each country, available with annual frequency. Excludes credit by central banks. Calculated using the following deflation method: $\left\{(0.5)^{*}\left[\mathrm{Ft} / \mathrm{P}_{-}\right.\right.$et $+\mathrm{Ft}-1 / \mathrm{P}_{-}$et- 1$\left.]\right\} /\left[\mathrm{GDP}\right.$ _ $/ \mathrm{P}_{-}$at $]$ 
where $\mathrm{F}$ is credit to the private sector, $\mathrm{P} \_$e is end-of period CPI, and $\mathrm{P} \_$a is average annual CPI. Source: Beck et al. (2010).

Foreign assets/GDP

Foreign liabilities/GDP

Government/GDP

Legal origin

Exports/Output

Imports/Output

External dependence

Growth opportunities

Liquidity needs
Average total foreign assets over GDP. Source: Lane and Milesi-Ferretti (2007).

Average total foreign liabilities over GDP. Source: Lane and Milesi-Ferretti (2007).

Average government spending as a share of total GDP. Source: Penn Tables.

A matrix of dummies for the origin of the country's legal system. Dummies take on the value of 1 if the respective country has English, French, German, or Nordic legal origin. Source: La Porta et al. (1998)

Average exports in a particular sector divided by output in a particular sector. Adapted for ISIC Rev. 3 from Di Giovanni and Levchenko (2007).

Average imports in a particular sector divided by output in a particular sector. Adapted for ISIC Rev. 3 from Di Giovanni and Levchenko (2007).

The sector's median value of capital expenditures minus cash flows divided by capital expenditures, for mature Compustat firms. Adapted for ISIC Rev. 3 from Cetorelli and Strahan (2006).

The sector's median value of capital expenditures minus cash flows divided by capital expenditures, for mature Compustat firms. Adapted for ISIC Rev. 3 from Fisman and Love (2006).

The sector's median value of total inventories divided by total sales, for mature Compustat firms. Adapted for ISIC Rev. 3 from Raddatz (2006). 
